\title{
Callimachus Romanus
}

\author{
Propertius' Love Elegy and the Aetiology of Empire
}

\author{
Alexander Kirichenko
}

\section{Introduction}

In the prologue to the fourth book of his elegies, Propertius announces that he will now sing of sacra diesque ... et cognomina prisca locorum (Prop. 4.1.69) and describes himself as a Romanus Callimachus (Prop. 4.1.64). ${ }^{1}$ On the surface, the text simply expresses the poet's intention to leave behind the erotic poetry of the first three books and to turn instead to the composition of Callimachean-style aetiological elegies. ${ }^{2}$ But this impression is complicated by the fact that, taken as a whole, Propertius 4.1 is doubtless one of the most bizarre programmatic poems in Augustan literature. The patriotic fervour, with which Propertius pledges to place his 'slender' - typically Callimachean poetic talent in the service of the fatherland, ${ }^{3}$ is suddenly interrupted, in the second half of the poem, by the Oriental astrologer Horos who, citing his unmatched prophetic gift, claims that the best thing that Propertius could do would be not to experiment with new topics but to continue what in the first three books he has proved he can do best - to sing of his love for the infinitely elusive girl. ${ }^{4}$ As a result, this nostalgic evocation of the poetic persona created by Propertius in his previous oeuvre blurs the apparent straightforwardness with which the poet stages his transition from erotic to aetiological poetry. The goal of this chapter is to show that, rather than simply point to the thematic heterogeneity of Book $4,{ }^{5}$ the juxtaposition of Propertius' patriotic manifesto and Horos' plea for more love elegy could be interpreted as an invitation to

1 All references are to P. Fedeli's Teubner edition.

2 See e.g. Miller 1982, 380-383. For more nuanced assessments, see e.g. DeBrohun 20o3, 9-13; Hutchinson 2006, 1-16.

3 Prop. 4.1.59-6o. Cf. 2.1.39-40.

4 Prop. 4.1.135-147. For a discussion of the poem's unity, see Miller 2004, 186; Hutchinson 2006, 59-62.

5 Hutchinson 2006, 16-21, who sees "discontinuity" as the main principle behind the organization of the book. See also DeBrohun 2003, 22-24, with references, on the growing awareness of the semantic complexity behind the book's thematic heterogeneity. 
perceive Propertius' earlier poems for Cynthia and his new aetiological poetry not as mutually exclusive options but as two intricately intertwined aspects of a single poetic project. ${ }^{6}$ But since in 4.1 Propertius not only presents himself as the author of Roman Aetia but also unmistakably derives the substance of his portrayal of Rome from Book 8 of Virgil's Aeneid, ${ }^{7}$ it would be impossible to appreciate the peculiarity of his aetiological construct unless one begins by juxtaposing it with these two literary models.

\section{From Archaic Aetiologies to Callimachus' Aetia}

One of the most conspicuous hallmarks of Greek aetiological myths is their capacity to conceptualize both cultural memory and political space. The standard 'ever since then' formula of aetiological narratives is indeed only possible in the presence of a material anchor (a natural feature, a monument, or a ritual) that can be declared to preserve the memory of how things were in the mythical past. ${ }^{8}$ But most Greek aetiological myths also involve movement in space. Myths of gods and heroes either traveling with the express goal to found a city or a sanctuary or simply leaving enduring traces on their longer journeys not only serve to account for the spread of Greek culture throughout the Mediterranean but also cohere into a mental map of socio-cultural links among countless Greek communities. ${ }^{9}$ Thus, in addition to creating the sense of physical continuity within specific locations, aetiological myths serve

6 Unlike those scholars who, with varying degrees of sophistication, regard the amor of Books 1-3 and the Roma of Book 4 as a pair of opposites (cf. e.g. DeBrohun 2003, esp. 24-28), I propose to interpret Propertius' elegiac amor as a means of conceptualization ('aetiologization'?) of Augustus' imperial Roma. Seen this way, Propertius' love elegy will emerge as a crucial contribution to the formation of a genuinely Roman version of the classical Greek discourse of 'political Eros', on which see Ludwig 2002; Wohl 2002; Scholtz 2007.

7 Cf. Hutchinson 2006, 6o.

8 Kowalzig 2007, 25-32, esp. 27: "The visible locality or the ritual space where the story happens or a rite is still to be observed form the most important link between the events portrayed in the aetiological tale and the religious reality which the myth seeks to explain. [...] After this one point of metamorphosis in a primordial time, the aition claims, the state of affairs has always remained the same." Cf. Asper 2013, 64-69.

9 Kowalzig 2007, 24: "Religious aetiology creates a map of Greece entirely shaped by itinerant gods, heroes and humans from a distant past, who establish cults and rituals, and set up and carry around cult images and other spoils from a time long ago. [...] Few are the cult places in Greece which are not either themselves the product of an individual story or linked into a mythical cycle [...]. If we traced all the voyages of the gods and heroes on a giant map of the Mediterranean, positioning little figures where they left behind a cult, few spots would remain blank." See also Annette Harder's and Jacqueline Klooster's chapters in this volume. 
to endow local traditions with a larger meaning by connecting them to the overarching network of shared cultural memories. ${ }^{10}$ As a result, what on the surface may look like a fragmented plurality of physical places forms a complex aetiological network held together by the invisible pull of a common mythical past.

In a similar manner, the myths told in Callimachus' Aetia stress not only temporal continuity within individual sites but also geographical links among them. Not only is there a constant emphasis in the Aetia on religious and social mobility, exemplified by pilgrimages to foreign lands, by the adoption of foreign cultic practices, or by marriages between members of different communities. ${ }^{11}$ In addition, a great number of the poem's narratives are written, as it were, on the margins of Panhellenic myths, connecting obscure local legends with the epic cycle or the myths of Heracles, Theseus, or the Argonauts. ${ }^{12}$ The result is the image of an infinitely interconnected world, in which every insignificant locality enjoys a respectable position within a greater scheme of things. ${ }^{13}$

But Callimachus' mental map of the Greek world projects an image that would have been inconceivable in the archaic period. Traditional aetiological myths view the Panhellenic world from their own local perspectives, so that the shared network of Greek civilization only emerges as a result of an overlap of those perspectives. In stark contrast to this multinodal structure, in the Aetia local aetiologies are perceived from Callimachus' own privileged

10 Cf. Malkin 2011, 3-64.

11 All references in this note are to Harder 2012, vol. 1: frgg. 43b-c (the festival of Theodaesia celebrated both on Crete and in Boeotian Haliartus), frgg. 67-75e (the marriage between Acontius of Ceos and Cydippe of Naxos as a paradigm of intermarriage), frgg. 8o-83b (the peace between Miletus and Myos is traced back to the Milesian king Phrygius falling in love with Pieria of Myos at an Artemis festival). In some stories, connections between individual communities are conceived of in terms of hostility: e.g. frgg. 31c-g (the statue of Artemis at Leucas wearing a mortar on her head is a reminder of Epirus invading Leucas), frgg. ${ }^{78-78 c}$ (the Ionians banning the inhabitants of Isindos from their religious festivals). Cf. Harder 2003, 294sq.

12 E.g. frgg. $3-7 \mathrm{~b}$ (the wreathless sacrifice to the Charites on Paros commemorates the death of Minos' son Androgeos), frgg. $7 \mathrm{c}-21 \mathrm{~d}$ (the aischrological ritual on the island of Anaphe traced back to the Argonauts' rescue from the Colchians), frgg. $22-23 \mathrm{c}$ (the fact that, on Lindos, the sacrifices to Heracles are accompanied by curses re-enacts the curses of the Lindian farmer whose bull was eaten by Heracles), frgg. $76 \mathrm{~b}-77 \mathrm{~d}$ (the marriage ritual at Elis commemorating Heracles destroying the city), frgg. 108-109a (the anchor of the Argo left on Cyzicus). On multiple Panhellenic "mythological frames" in the Aetia, see Acosta-Hughes and Stephens 2012, 177-193. Cf. Harder 2003, 296-302.

13 Selden 1998, 323-329, esp. 324: "In the four books of Aetia, Callimachus compiles divarications through which diverse heterotopic details have been lifted out of their proper setting and transferred to another context: an observance, a name, a festival, an institution." For a detailed discussion of Callimachus' 'geopoetics', see Asper 2011. 
viewpoint equidistant to all of them. ${ }^{14}$ Moreover, while traditional aetiological myths aim to explain the origins of physical elements of local landscapes or rituals, Callimachus' standpoint is detached from the original 'material' features that his aetiologies set out to explain. ${ }^{15}$ As a result, instead of the plurality of physical places loosely tied into a network of shared cultural memories, we have a materialized centre from which individual physical places can be perceived only as objects of memory. This centre is cast in the Aetia not simply as a notional Mouseion, conjured up by Callimachus' conversation with the Muses - a place where the scholar-poet pedantically stores obscure local myths for the intellectual pleasure of other cognoscenti. ${ }^{16}$ Rather, this centre is constituted by Alexandria itself - a Panhellenic city that has no tangible Greek past of its own and whose past and cultural identity can only be constructed as a sum total of the cultural memories of its recently arrived Greek inhabitants. ${ }^{17}$

It is particularly the scene of the banquet at the house of the Athenian immigrant Pollis (Call. Aet. fr. 178) that draws attention to the emergence of a new cultural reality in Alexandria. ${ }^{18}$ One of the most striking things about this scene is a contrast between Callimachus' attitudes to different sets of aetiological lore - the matter-of-fact tone with which he briefly refers to the well-known aetiological background of Athenian festivals celebrated by Pollis at his private house $^{19}$ and the enthusiasm with which he literally jumps on Theogenes, a guest from the utterly insignificant island of Icus, in order to learn the mythical origins of a particularly bizarre ritual. ${ }^{20}$ The juxtaposition of these two sets of aetiological lore creates the image of Alexandria as a society in which not

14 On "the Libya-centric geography" of the Aetia (Alexandria, strictly speaking, being a part of Libya: Stephens 2003, 181sq.), see Acosta-Hughes and Stephens 2012, 171-173.

15 Cf. Asper 2013, 69-77.

16 On Callimachus' notorious 'learnedness', see e.g. Schmitz 1999. More generally, on the 'learnedness' of Alexandrian poetry, see Bing 1988. On Callimachus' Mouseion, see Männlein-Robert 2010.

17 A similar image of Alexandria as a Panhellenic space is conjured up in Theocritus' Idyll 15 . See Selden 1998; Asper 2011, esp. 176sq., on the "Ptolemaic measures to unify the heterogeneous Greek population in Egypt". Cf. Acosta-Hughes and Stephens 2012, 202sq.

18 Fantuzzi and Hunter 2004, 76-83.

19 The allusive tone in which Callimachus lists the typical characteristics of Pithoigia, Choes, and Aiora (Call. Aet. fr. 178.1-4) shows how familiar - from literature rather than from autopsy - he expects those festivals to be to his readers. For the literary texts explicating the aetiological details alluded to by Callimachus, see Habash 1995, 567-574 (E. IT 947-96o and Ar. Ach. 96osqq.) and Rosokoki 1995 (Eratosthenes' Erigone).

20 Call. Aet. fr. 178.21-22. The ritual commemorated Peleus' shipwreck at Icus and involved a young girl carrying an onion: Call. Aet. fr. 178.25, Harder 2012, vol. 2, 953. For Phanodemus' Iciaca ( $\mathrm{FGrH}_{325} \mathrm{~T}_{7}$ ) as Callimachus' possible source, see Benedetto 2011, $361-363$, with references. 
only is every Greek a priori a stranger, but in which each stranger's cultural heritage is equally valuable, irrespective of whether they come from Athens or even from Icus.

The banquet stages an almost impossible mixture of different cultural protocols. The Athenian festival(s) of the Anthesteria and/or Aiora celebrated by Pollis is a carnivalesque public celebration of new wine that involves a drinking contest - the gulping down of huge quantities of undiluted wine, ${ }^{21}$ which strikes Callimachus as a barbaric custom. ${ }^{22}$ But at Pollis' house, the recreation of this tradition is part of a private symposium - a ritualized occasion that, as we know from numerous fragments of archaic Greek elegy, fostered a radically different attitude to wine-drinking by promoting moderation and self-restraint. ${ }^{23}$ It is precisely this conventionally sympotic stance that both Callimachus himself and his new best friend from Icus so eagerly endorse in that they drink wine mixed with water while engaging in a civilized table talk. ${ }^{24}$ In their original contexts, these two cultural protocols would have been utterly incompatible with each other, ${ }^{25}$ but at Pollis' house they easily coexist side by side - so that every guest can find a niche that best suits his inclinations. As a consequence, the only kind of 'like-mindedness' that can be attributed to Pollis' guests ${ }^{26}$ - or, by extension, to the Greeks in Alexandria in general seems to consist in their readiness, if not to embrace, then at least to tolerate their mutual differences. ${ }^{27}$

But Callimachus' portrayal of Alexandria goes beyond the construction of a 'politically correct' multicultural space. The two framing poems of Books 3 and 4 of the Aetia (Victoria Berenices and Coma Berenices) enact the process of

21 For a detailed discussion of both literary and archaeological sources on the Athenian Anthesteria, see Hamilton 1992. See also Maurizio 2001.

22 Call. Aet. fr. 178.11-12.

23 Cf. Murray 1990; Schmitt Pantel 1992; Hobden 2013. For a discussion of sympotic, not only elegiac, poetry as evidence for the archaic symposium as a model of social cohesion within the polis, see Corner 2010.

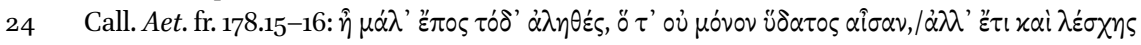
oivos है $\chi \varepsilon เ \nu$ ह่ $\theta \dot{\varepsilon} \lambda \varepsilon$. Cf. Scodel 1980.

25 The communal drinking of wine mixed with water at the symposium forms a sharp contrast both to Aiora, which commemorated the murder of Icarius by shepherds drunk on undiluted wine, and to Choes, which included a contest in drinking neat wine (cf. Ar. Ach. 1229) - a ritualized re-enactment of Orestes' solitary wine-drinking: Fantuzzi and Hunter 2004, 79. See also Corner 2010, on the symposium as a microcosm of the 'middling' ideology of the polis, and Maurizio 2001, on the Anthesteria enacting a carnivalesque 'hysteria' that serves to transcend and destabilize civic identity.

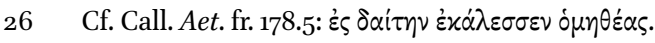

27 For the heterogeneity/'otherness' of the Greek population of Alexandria, see Selden 1998; Asper 2001. 
fusion of the cultural memories of Alexandria's Greek immigrants into something approaching a new common identity. In his epinician to Berenice, ${ }^{28}$ Callimachus establishes a parallel between the queen's return from the Nemean games and the wanderings of Io - both an alias of the Egyptian goddess Isis and a mythical ancestor of numerous Greek heroes. ${ }^{29}$ This parallel makes Ptolemaic Egypt appear not like a foreign place anymore but like a common source of 'Hellenicity' to which all Greeks are now, as it were, invited to 'return'.

If the Victoria Berenices positions Egypt at the very centre of the conceptual space of Greek culture, the Coma Berenices conceives of the centrality of Alexandria in terms of aetiological time. ${ }^{30}$ The striking 'discovery' by the court astronomer Conon that a lock of the queen's hair has been transformed into a constellation is presented as the basis of a new state cult to be celebrated (at least according to Catullus' Latin translation of the poem) by every woman on her wedding night. ${ }^{31}$ The narrative is obviously based on the same myth-and-ritual pattern as the local aetiologies told in the rest of the Aetia. ${ }^{32}$ But it is the difference between the Coma Berenices and traditional aetiologies that is particularly revealing. This aetiological miracle takes place not in an immemorial mythical past but in the here and now of contemporary Alexandria; the object whose origin it purports to explain is not an obscure quirky-looking statue but a phenomenon of universal proportions visible to the entire world from now and for all eternity; and what it does is not to validate a local custom by appealing to the common Panhellenic past but to imagine a (perhaps somewhat grotesque) mechanism for the penetration of the Ptolemaic royal cult into the privacy of every single bedroom, potentially around the whole world. ${ }^{33}$ To all those Greeks, whose local cultural memories

28 See Fuhrer 1992; Fantuzzi and Hunter 2004, 83-85; Harder 2012, vol. 2, 384-392.

29 Victoria Berenices, fr. 54 (Harder $=$ SH 254): Acosta-Hughes and Stephens 2012, 163-170 and $185^{-187}$, with a full discussion of references to various Panhellenic myths (Helen, Proteus, Io) in the poem.

30 Cf. Gutzwiller 1992. On the shift in aetiological time in the Coma Berenices ("the present as the past of the future"), see Harder 2003, 302-304.

31 Catul. 66.79-86. For a discussion of the connection between Callimachus' and Catullus' versions of the poem, see Harder 2012, vol. 2, 793-795. See also Gutzwiller 1992, 381sq., following Pfeiffer: "[T] he suggestion that Catullus invented the ai $\tau$ iov is unconvincing, because the ritual is just the sort of cult practice we would expect the Euergetai to establish in order to perpetuate the myth of their romantic marriage." Cf. Hollis 1992; Jackson 2001; Clayman 2011, 240-242.

32 Harder 2003, 303.

33 Cf. Prioux 2011, 207. On the Egyptian background of the catasterism, see Koenen 1993, 105-108; Selden 1998, 326-354. 
constitute the bulk of the Aetia, this ideological construct would make the contemporary reality of Ptolemaic Alexandria appear like a new time of origins on a par with the mythical time of gods and heroes. As a result, the partial analogy between the structure of local aetiologies and the structure of royal ideology effectively turns the Aetia into an account of the 'causes' of Alexandria itself - an account that begins by constructing the city's Panhellenic identity from a mixture of the local cultural memories of its Greek inhabitants and then engulfs those memories into a single totalizing vision projected by the royal cult.

By focusing on the hospitable reception of the Trojan refugee Aeneas by the Arcadian immigrant Evander, Virgil's Aeneid 8 casts pre-historical Latium as a country that is as welcoming to foreigners as Callimachus' contemporary Alexandria. ${ }^{34}$ The similarity between this episode of the Aeneid and the Aetia is underscored by the fact that Aeneas' visit with Evander is based on Heracles visiting Molorcus in the Victoria Berenices ${ }^{35}$ - the poem that, as I pointed out above, most crucially contributes to enhancing the sense of social cohesion of Alexandria's culturally diverse population. In addition, Virgil follows Callimachus in using the 'ever since then' reasoning of aetiological myths in order to conceptualize the functioning of contemporary ideology.

On the one hand, Virgil draws a contrast between Pallanteum, the precursor of Rome that consists of nothing but a citadel and a few scattered huts, and contemporary Rome, the imperial city that 'equals the sky' ${ }^{36}$ But on the other, the proto-Rome visited by Aeneas is a cultural landscape already thoroughly imbued with aetiological memories, which still persist into the reader's Augustan present. Aeneas' arrival coincides with the celebration of Hercules' victory over Cacus at the ara maxima, a notable feature of the Augustan cityscape whose aetiological rationale Evander traces back to the earliest stages of Greek mythical past. ${ }^{37}$ And on the whole, the pre-historical city that Evander so eagerly shows his Trojan guest turns out to possess numerous 'reminders

34 Reed 2007, esp. 3-5, on the Aeneid dramatizing "our sense of the Roman not just as the combination of Trojan and Latin, but as forged out of cross-cultural exchanges from many sides".

36 Verg. A. 8.98-10o. Cf. Verg. A. 8.347-348: Edwards 1996, 31sq.

37 On the significance of the Heracles and Cacus episode in the ideological fabric of the Aeneid, see Morgan 1998. 
of the men of the past' (virum monumenta priorum, Verg. A. 8.312; cf. reliquias veterumque ... monumenta virorum, 356). The very name of Latium is etymologically derived from the fact that Saturn, who introduced agriculture into the land previously inhabited only by the uncivilized Nymphs and Fauns, found here a refuge from Jupiter's pursuit (latuisset, Verg. A. 8.323). ${ }^{38}$ Furthermore, Aeneas sees the porta Carmentalis, one of Rome's city gates, which is now said to commemorate the 'ancient' (even from Aeneas' standpoint) honor accorded to the nymph Carmentis who was the first to predict the future glory of Aeneas' descendants and of 'noble Pallanteum.' ${ }^{39}$ In a similar vein, Evander continues to trace the origins of the names and functions of further familiar features of the Augustan cityscape to a mythical past that, obviously, predates the arrival of Aeneas - the name of the Lupercal derived from the Arcadian Pan Lycaeus ${ }^{40}$ and the temple of Jupiter Capitolinus on the Tarpeian Rock built on the spot where Evander's Arcadian fellow-immigrants claim to have seen Jupiter himself. ${ }^{41}$ Even at this early stage of its hoary pre-history the landscape surrounding the future site of Rome is already marked by crumbling, still more pre-historical, ruins - the citadels built by Janus and Saturn. ${ }^{42}$

Like the numerous individual locations of the Greek world conjured up in Callimachus' Aetia, Virgil's Rome is cast as a material carrier of aetiological memories. ${ }^{43}$ But the obvious difference between Callimachus' mental map of the vast expanses of the Mediterranean and Virgil's circumscribed cityscape is more than a difference in scale. This difference crucially affects the manner in which Callimachus and Virgil conceptualize their respective imperial centers. While Callimachus' Alexandria is a blank slate that can only derive cultural meaning from the sum total of the aetiological memories of its newly arrived Greek immigrants, Virgil's Rome is a unique place that is always already oversaturated with materially tangible cultural memories, which point both to the mythical past and to the vast world outside the city's narrow confines. ${ }^{44}$ It is probably for this reason that the analogy that Virgil draws between ancient aetiologies and contemporary imperial politics results in a much more coherent ideological construct. Virgil achieves this effect by unobtrusively making narrative and/or historical events appear to follow the basic mechanism of aetiological myths re-enacted in rituals - by portraying Aeneas' victory over Turnus

\footnotetext{
$38 \quad$ O'Hara 1996, 207sq.; Rimell 2015, 33sq.

39 Verg. A. 8.337-341. On the etymological wordplay here, see O'Hara 1996, 209.

40 Verg. A. 8.342-346: O'Hara 1996, 209sq.

41 Verg. A. 8.347-354, esp. 352-353: Arcades ipsum/credunt se vidisse Iovem.

42 Verg. A. 8.356-358. Cf. Edwards 1996, 11 and 31sq.

43 Cf. Tueller 2000.

44 Cf. Edwards 1996, 10-15, on Rome as "always already an especially time-laden place".
} 
as a notional re-enactment of Hercules' victory over Cacus and Augustus' triumph over Antony and Cleopatra as a notional re-enactment of Hercules' and Aeneas' victories. ${ }^{45}$ As a result, Rome itself - Evander's Pallanteum morphing into the temple of Apollo on the Palatine, the main monument to Augustus' victory at Actium ${ }^{46}$ - emerges as a ritual space that compresses Roman history, from its mythical past to its imperial present, into a sequence of habitually enacted triumphs, while the Aeneid as a whole becomes a kind of an aetiological account of the emergence of empire - an account that effectively conceives of heroic myth as the 'origin' of Augustus' imperial power.

Thus, the main difference between Callimachus' and Virgil's aetiological constructs has to do with the fundamental difference between their spatial/ temporal parameters. While Virgil echoes Callimachus in turning aetiology into an instrument of ideology, he replaces Callimachus' centripetal model of a new metropolis attracting immigrants from the entire Greek world with the centrifugal model of an infinitely expanding universal empire. As we have seen, Callimachus conjures up the image of a newly founded Panhellenic city, whose past consists of imported cultural memories and whose universal appeal is largely predicated upon the (arguably) rather dim light shed by the fanciful constellation of the Lock of Berenice. By contrast, Virgil's imperium sine fine (Verg. A. 1.279) is both firmly rooted in the past and incontestably real: the city of Rome is not only endowed with rich cultural memories of its own, but those memories also provide a kind of an aetiological foundation for its determination to subdue any as-yet unconquered territories on the remotest margins of the empire.

\section{$4 \quad$ Callimachus and Virgil in Propertius 4.1}

Propertius 4.1 is doubtless one of the most consistent adaptations in Augustan poetry of the image of Rome painted in Aeneid $8 .{ }^{47}$ At the beginning of the poem, Propertius echoes Virgil's Evander giving a tour of proto-Rome to his Trojan guest in that he, too, addresses a hospes whom he urges to imagine what Rome may have looked like prior to the advent of 'the Phrygian Aeneas'

45 For a detailed discussion of the 'aetiological' conjunction between Hercules, Aeneas, and Augustus staged in Aeneid 8 in the ritual space of Pallanteum/the Palatine, see Kirichenko 2013, 79-86, with references.

46 Miller 2009, $185^{-252}$. On the etymological wordplay between Pallanteum and the Palatine, see O'Hara 1996, 202.

47 On connections between Propertius 4.1, Tibullus 2.5, and Virgil's Aeneid 8, see Hutchinson 2006, 6o. 
(Prop. 4.1.2). Like Virgil, Propertius draws a contrast between the visually unimpressive rustic beginnings of Rome and the stunning imperial city familiar to his readers (Prop. 4.1.1-38). And like Virgil, he conceives of the rise of Rome as a rebirth of Troy and implicitly suggests that there may be a parallel between Aeneas overtaking Latium and Augustus' regaining control over empire. ${ }^{48}$

But on closer scrutiny, these parallels serve to draw attention to the fundamental difference between Virgil's and Propertius' conceptions of the relationship between mythical past and historical present. While for Virgil the Augustan present of Rome is, as it were, aetiologically preordained by its (pre)-Aenean past, Propertius persistently stresses an astonishing gap between past and present. In stark contrast to Virgil's Pallanteum that Aeneas finds filled to the brim with multi-layered cultural memories, the maxima Roma that Propertius introduces to his hospes was, prior to Aeneas' arrival, a domain of nature nothing but 'hill and grass' (Prop. 4.1.2 collis et herba) inhabited only by cows, sheep, and herdsmen. ${ }^{49}$ For over thirty lines, Propertius continues in this vein, presenting the first origins of Rome as a pristine bucolic landscape conceived of, by contrast with such modern architectural marvels as the temple of Apollo on the Palatine (Prop. 4.1.3), as cultural void, which, rather than preserve aetiological memories of unique mythical events, merges with the predictable cycles of nature..$^{50}$ Propertius lets this bucolic timelessness continue unabated until the time of Romulus, who, suckled by the Capitoline wolf, functions as

48 Cf. Propertius' Virgilian trajectory from Rome as Troy reborn (Ilia tellus/vivet, Prop. 4.1.5354) to the temple of Apollo on the Palatine as a monument to Augustus' triumph over the foes of empire, whose construction produces the same conceptual effect as the advent of Aeneas: before Aeneas, Rome was only 'hill and grass' (Prop. 4.1.2); where the Apollo temple stands now, there were only Evander's cows (atque ubi Navali stant sacra Palatia Phoebo,/Euandri profugae concubuere boves, Prop. 4.1.3-4).

49 Prop. 4.1.7-30: Edwards 1996, 41sq. Cf. Rothwell 1996; Fantham 1997.

50 Propertius persistently defines the primordial landscape of Rome in terms of negation of cultural, religious, and political symbols that characterize it now - cows instead of the Apollo temple (4.1.3-4), the Tarpeian rock without the temple of Jupiter Capitolinus (Tarpeiusque pater nuda de rupe tonabat, 7), the Tiber flowing only for the cattle (8; for a discussion of this probably corrupt line, see Hutchinson 2006, ad loc.), a single hearth as an equivalent of a kingdom instead of the modern temple of Quirinus (unus erat fratrum maxima regna focus, 10), the Curia holding skin-clad rustics (pellitos ... rustica corda, Patres, 12), a shepherd's horn calling Romans to assemble (bucina, 13), and the senate meeting in a meadow (15-16). Likewise, Roman religious festivals, such as the annual pastoral festival of Parilia (19-20) and the sacrifices to Vesta (21-22), did not worship foreign gods (= re-enact foreign myths? 17-18) but simply mirrored 'nature': e.g. the 'licentious' rite of the luperci Fabiani imitated the ploughman whipping his bulls with a thong $\left(25^{-26}\right.$; see Hutchinson 2006, ad loc., for the evidence on the cult). Cf. Barchiesi 1997, 188, n. 7, on these lines as a summary of the Roman cult calendar. 
an icon of autochthonous origin par excellence. ${ }^{51}$ This ahistorical continuum simply skips over the pivotal event that, for Propertius, marks the introduction of culture into this pristine natural landscape - the advent of the 'Phrygian Aeneas' presented at the very beginning of the poem as the paradigm-shifting event responsible for the emergence of Rome's imperial grandeur.

Thus, Propertius presents the origins of Rome as irreducibly twofold (cf. hinc, 4.1.31 and 45): they can be traced either to the primordial collis et herba or to the Iliadic hero who brings this pristine landscape previously unspoiled by foreign culture into the orbit of Greek civilization. The visual images that constitute the cityscape of Propertius' Rome point only to the Aeneas legend - the temple of Apollo on the Palatine that can indeed be construed as evidence of the rebirth of Troy. ${ }^{52}$ But such imperial 'golden temples' serve to erase the memories of the original collis et herba and of the 'clay gods' which they had replaced. ${ }^{53}$ The only link between the imperial Rome of today and the city's bucolic origins consists for Propertius in the word Rome itself - one name given to two fundamentally different things. ${ }^{54}$ Unlike in Virgil, the rustic past and the contemporary 'golden' appearance of Rome are linked to each other neither by aetiological reasoning nor by materially graspable cultural memories, not even by a tenuous analogy. Quite the contrary: the main tenor of the poem is the wonder caused by the striking discrepancy between the original emptiness and the currently observable cultural plenitude and imperial omnipotence.

By portraying Rome as a blank slate transformed into an awe-inspiring centre of imperial power Propertius not only diverges from his Virgilian model but also indirectly evokes Callimachus' Aetia where, as we have seen, Alexandria's stunning political authority is similarly constructed as arising, as it were, from a void filled with imported cultural paradigms. Propertius seems to follow in Callimachus' footsteps by casting his own elegiac poetry, too, as an imaginary space that forms an analogy to, and thereby conceptualizes, the political space of his imperial city.

$5^{1} \quad$ Prop. 4.1.32: quattuor hinc albos Romulus egit equos and 38: sanguinis altricem non pudet esse lupam.

$5^{2}$ See n. 49 above. See Stahl $1985,255^{-260}$, who reads 4.1 as "a review of Rome's history from the viewpoint of the Julian family." Cf. Welch 2005, 21.

53 Prop. 4.1.5: fictilibus crevere deis haec aurea templa.

54 Prop. 4.1.37: nil patrium nisi nomen habet Romanus alumnus. Given the fact that the only traceable continuity between past and present is of purely verbal nature, it is hardly surprising that in Book 4 (Varronian?) etymology becomes an important method of accounting for the passage of time in aetiological terms. See esp. Vertumnus etymologizing his own name at 4.2.9-12. Cf. Fantham 1997. 
In his polemics against the Telchines in the prologue to the Aetia, ${ }^{55}$ Callimachus appeals to the history of elegy as a genre, in order to determine what kind of elegy is most appropriate for writing about the origins of Alexandria. ${ }^{56}$ As Ewen Bowie has shown in an influential article, there were two basic forms of archaic elegy - short, thematically diverse pieces recited at symposia and longer, chronologically continuous poems (cf. हैv $\alpha^{\prime} \varepsilon ı \mu \alpha \delta \eta \eta-$

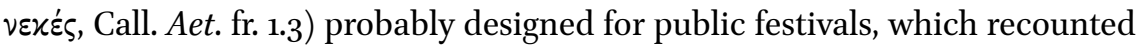
local foundation legends and which, needless to say, included tales of 'kings and heroes' so bitterly missed by the Telchines (cf. Call. Aet. fr. $1.3-5) \cdot{ }^{57}$ And in his response to the Telchines, Callimachus indeed seems to be drawing a contrast between precisely these two types of elegies - the short elegant poems by Mimnermus and Philitas contrasted with their long ktistic poems on the

55 The prologue is doubtless the most discussed passage of the Aetia. For the enormous bibliography on the prologue, see Harder 2012, vol. 2, 6-93. My discussion of the prologue to the Aetia is based on Kirichenko 2017.

$5^{6}$ According to the standard reading, based on the (fictitious) tradition of the quarrel between Callimachus and Apollonius of Rhodes and indirectly buttressed by the countless imitations of the Aetia prologue in Roman poetry, Callimachus defends his elegiac poetry against the proponents of traditional epic. See e.g. Schwinge 1986; Zanker 1987, 155sq.; Asper 1997, 217-224. Alternative readings include Cameron 1995, esp. 303-338, who sees Antimachus' Lyde, a long elegiac catalogue of mythological love stories, as the main target of Callimachus' polemics, Barbantani 2002, according to whom Callimachus draws a contrast between his own collection of short elegies and contemporary historical/ encomiastic poems in elegiac couplets such as $S H 95^{8}$ (P.Hamb. 312, inv. 381), and Harder 2012, vol. 2, 10-11, who interprets the prologue "as referring to poetic style and quality in general". By contrast, my interpretation of the prologue takes into account not only formal characteristics (long vs. short, or 'cyclic' vs. 'polished'), but also content, function, and dramatic setting. In my view, the Telchines' discontent with the Aetia only becomes understandable as a reaction to what they see as a discrepancy between content (grand

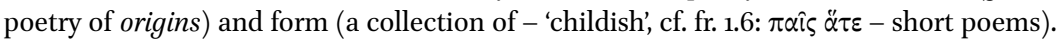
For a similar view of the literary polemics in Callimachus' Hymn to Apollo (traditionally interpreted, like the polemics in the prologue to the Aetia, as an opposition between long epic poetry and Callimachus' own short poem), see Kirichenko 2010, where Phthonos' disappointment is shown to arise from his having expected a hymn of an appropriate length along the lines of the Homeric Hymn to Apollo.

57 Bowie 1986, esp. 15-21 (on the symposium, pace West 1974, as the only context securely attested for the performance of short elegiac poems irrespective of their content - sympotic, erotic, or martial/exhortatory) and 27-34 (on the performance at public festivals of long, 1000 lines and longer, ktistic/historical elegies, such as Mimnermus' Smyrneis (a history of the city of Smyrna, which took its name from an Amazon), Tyrtaeus' Politeia/ Eunomia, Semonides of Amorgos' Archaeologia, Xenophanes' poem on the foundation of Colophon and the colonization of Elea, Panyassis' Ionian history, and, possibly, Ion's Ktisis of Chios). See also Dougherty 1994. 
histories of Smyrna and Cos. ${ }^{58}$ In this connection, the criticism of the Telchines may indeed be construed as a reaction to the discrepancy between the poem's title and its form. Primordial traditionalists that they are, the Telchines seem to expect from an elegiac poem entitled $\tau \dot{\alpha} \alpha{ }^{\prime} \tau \iota \alpha$ and written by a poet based in Alexandria to be a continuous account of the city's origins. ${ }^{59}$ But instead, they get a collection of short 'sympotic' pieces, whose indebtedness to the archaic tradition of sympotic poetry becomes apparent not only in the episode of the banquet at Pollis' but also because Callimachus' conversation with the Muses in the first two books also seems to be conceived as a kind of table talk. ${ }^{60}$ What escapes the Telchines, however, is that it is precisely the form chosen by Callimachus - a formally unified collection of short aetiological poems that is ideally suited to account for the origins of the Panhellenic metropolis of Alexandria as a fusion of the local cultural memories of its Greek immigrants. ${ }^{61}$ In the prologue to Book 4, Propertius also casts his own poetry as an icon of the political time/space of the city that he seeks to glorify. His astonishment at the great city walls of Rome that, implausibly enough, have 'grown out of the milk of the Capitoline Wolf'62 is translated into a determination to erect

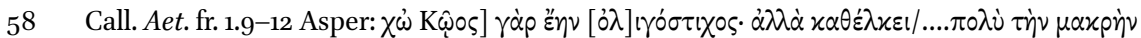

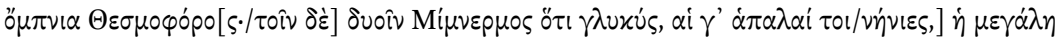

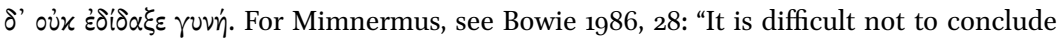
that Nanno is the title of one book [sc. of Mimnermus], Smyrneis of the other, and West made a strong case for Nanno being a collection of short poems. In that case Callimachus'

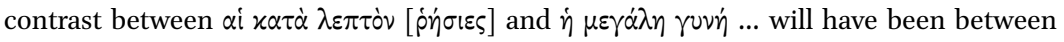
Nanno and the Smyrneis," and 29sq., on the Smyrneis as a poem treating the foundation of Smyrna. For the evidence on Philitas' poem on Cos, see Sbardella 200o, 28-41, esp. 39 on the possibility of this poem being "non dissimile, sotto l'aspetto tematico, dai poemi di fondazione o ktiseis".

59 Tellingly, Apollonius of Rhodes was the author of a number of ktistic poems, one of them

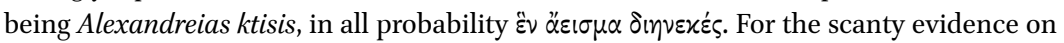
these poems, see Sistakou 2008.

6o See Call. Aet. fr. 43, esp. 12-17. For a thorough discussion of frgg. 178 and 43 as framing the "second book of the Aetia as a sympotic discourse" (Callimachus telling the Muses some of the stories that he had heard at Pollis' symposium), see Acosta-Hughes and Stephens 2012, 140-145. Cf. Cameron 1995, 133-137; Fantuzzi and Hunter 2004, 8osq; Harder 2012, vol. 2, 955sq. Most revealingly, a great portion of fr. 43 (vv. 46-92) is a catalogue of ktiseis (foundations of Sicilian cities) leading up to Clio's detailed narrative of the foundation of Zancle.

61 Cf. Selden 1998, 325, who describes the world conjured up in the Aetia as "an uncircumscribed series of discrete sites, each of which marks in turn an intersection of diverse itineraries and is hence constituted as a set of historic and geographic alibis. The text itself here functions as the mastersite for their collocation."

62 Prop. 4.1.55-56: optima nutricum nostris, lupa Martia, rebus,/qualia creverunt moenia lacte tuo! 
figurative 'city walls' in his own 'pious verse' (moenia namque pio coner disponere versu, Prop. 4.1.57). ${ }^{63}$ The origin of these poetic 'city walls' is as paradoxical as the origin of Rome itself. For despite its proverbially Callimachean slenderness, Propertius' poetry is predestined to overshadow the fame of Ennius, the paradigmatic poet of Rome's origins whose 'shaggy crown' (hirsuta corona, Prop. 4.1.61) now conceptually places him smack in the middle of the city's pre-civilizational landscape. ${ }^{64}$ Furthermore, Propertius predicts that these metaphorical 'city walls' of Rome will bestow glory on the 'citadel walls' of his own Umbrian hometown (scandentis quisquis cernit de vallibus arces,/ingenio muros aestimet ille meo, Prop. 4.1.65-66). ${ }^{65}$ The image of Rome as a stunning artifact forever transforming the original, purely natural, landscape is effectively reified in Propertius' image of the genesis of his own poetic artefact radically transforming the existing cultural landscape and, therefore, destined for immortality.

But Propertius' prologue evokes not only the characteristically Callimachean 'geo-poetics', which conceptualize political space by mirroring it in the notional space of poetry, but also the dialogic nature of the prologue to the Aetia. Just as the core of the Aetia prologue consists in Callimachus' dialogue with the nit-picking Telchines, so in his prologue, too, Propertius juxtaposes two speeches - his own programmatic statement and its critique by the Egyptian astrologer Horos. Horos recycles in his speech a number of recognizably Callimachean motifs in order to advance a patently non-Callimachean cause. On the surface, Horos' soliloquy is one of the numerous Augustan adaptations of the passage from the prologue to Callimachus' Aetia in which Apollo encourages the poet to persist in his determination to compose experimental poetry, never 'traveling down a well-trodden path.' ${ }^{66}$ But in stark contrast to all other reflexes of this Callimachean passage in Roman poetry, Horos transforms this manifesto of poetic innovation into a deeply conservative, 'Telchinian'

63 On the parallelism between Augustus' material city and Propertius' textual city, see Edwards 1996, 7. For the image of Propertius as a 'city-builder', see also DeBrohun 2003, 42; Welch 2005, 25-27, with further references.

64 Cf. Hutchinson 2006, 72: "The line of thought connects with the rusticity of early Rome in 1-38: hairiness is characteristic of the archaic and the countrified."

65 Cf. Edwards 1996, 55. For a reading problematizing the tension between the walls of Rome, which Propertius intends to construct, and the walls of Assisi, which he intends to glorify, see DeBrohun 2003, 86-117.

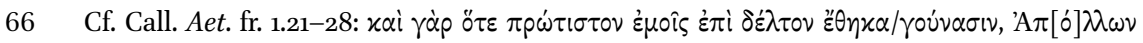

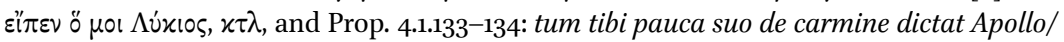
et vetat insano verba tonare Foro. Cf. Verg. Ecl. 6.3-5. See Hutchinson 20o6, ad loc. On the reception of Callimachus' programmatic poetics in Roman poetry in general, see Wimmel 196o; Thomas 1993; Cameron 1995, 454-483; Hunter 2006. 
rather than Callimachean, plea - into an attempt to talk Propertius out of his plan to write aetiological poems and instead to return to the 'business as usual', to the composition of love elegies in the spirit of Books 1-3. ${ }^{67}$

No less significant is that Horos derives his pedigree from Conon - the Ptolemaic court astronomer mentioned in Callimachus' Aetia as the 'discoverer' of the catasterism of the lock of Berenice. ${ }^{68}$ This parallel, too, serves to underscore the patently 'non-Callimachean' nature of Horos' voice. Within the Aetia, Conon's discovery serves to authenticate Callimachus' adaptation of aetiological reasoning to royal ideology, so that Conon's astronomical wisdom cum ideological inventiveness may in fact be regarded as conceptually coextensive with Callimachus' erudite and experimental writing. ${ }^{69}$ Propertius' Horos is, by contrast, a comical figure devoid of independent authority: he corroborates his astrological credentials by citing silly banalities, literary clichés, and prophetic mumbo-jumbo, ${ }^{70}$ and his knowledge of Propertius' previous life (most notably of Apollo appearing to the poet in his youth to urge him to write love elegy) is for the most part derived from Propertius' own poetry. ${ }^{71}$ Unlike Callimachus' Conon, Propertius' Horos is capable of no cosmic revelations. Rather than the poet's alter ego, Horos seems to be cast as an enthusiastic fan of Propertius' love elegy, a fan prepared to go to any lengths to obtain from his favorite poet more of what he already holds dear.

67 Prop. 4.1.135-146: at tu finge elegos, fallax opus, etc. On the mixture of Callimachean voices in the figure of Horos, see also DeBrohun 2003, 19-22.

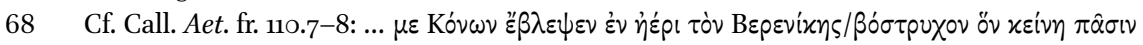

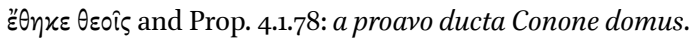

69 On the ideological ingenuity of Conon's 'discovery', see Gutzwiller 1992, 362-373.

70 For silly banalities, see Prop. 4.1.89-106 (Horos predicting that Arria's twin sons departing for war will die in battle and ordaining Cinara lying in labor to make a vow to Juno - a standard religious practice, which, comically enough, Horos claims she would have never learnt if she had consulted the oracle of Zeus Ammon, a haruspex, an augur, or a necromancer); for literary clichés, cf. 4.1.107-118 (Horos contrasting his infallible prophetic art with Calchas' prophecy, both impious and inaccurate, which urged Agamemnon to kill his own daughter but failed to predict the tragic nostoi of the Greek heroes); and for prophetic mumbo-jumbo, see the highfalutin injunction at 4.1.15o: octipedis Cancri terga sinistra time. Cf. Coutelle 2005, 521-534. For a brief discussion of different attempts to endow Horos' sinister constellation of the 'eight-footed Crab' with a decipherable meaning, see Hutchinson 2006, 85sq.

71 Horos' description of Propertius' homeland at 4.1.121-126 echoes Propertius' own description at 4.1.63-66; the mention of the funeral of Propertius' father at 4.1.127-128 echoes the funerals lamented by Propertius in 1.21 and 1.22 (esp. 7-8: tu proiecta mei perpessa es membra propinqui,/tu nullo miseri contegis ossa solo; cf. DeBrohun 2003, 13-15); and the Callimachean epiphany of Apollo at 4.1.133sqq. points back to Propertius' earlier appropriation of that portion of the Aetia prologue in 3.3. Cf. also Apollo's (or Horos'?, see Hutchinson 2006, 84) at tu finge elegos ... haec tua castra! and 2.7.15: meae ... castra puellae. 
But although, as a faithful fan, he can effortlessly reproduce some of the most memorable concepts of Propertius' erotic poetry - such as, most prominently, militia and servitium amoris ${ }^{72}$ - Horos completely fails to appreciate the Callimachean spirit of poetic/ideological experimentation that Propertius enacts in 4.1. Thus, despite his sympathetic tone, Horos is a 'Telchinian' figure. And as I would like to show now, the role that Horos plays in Propertius is indeed similar to that of the Telchines in Callimachus' Aetia. Just as the Telchines' demand for a conventional ktistic linear narrative enables Callimachus to parade his loose collection of aetiological elegies as a poetic form best suited to conceptualize the 'origins' of Panhellenic Alexandria, so Horos' demand for more erotic poetry, too, allows Propertius to showcase his love elegy as a poetic genre indispensable for the conceptualization of the 'aetiology' of the Roman Empire. ${ }^{73}$ Like Callimachus, Propertius conceives of his imperial city in terms of absence, but what it means for Propertius to be a Roman Callimachus is to replace memory with desire as a figure of absence - to replace Callimachus' image of Alexandria as a projection of obscure local aetiologies with the image of Rome as a locus of the insatiable desire for imperial domination.

\section{5}

\section{Propertius 1-3: eros and imperium}

Propertius' love for Cynthia in Books ${ }^{1-3}$, a fixation that admits of no alternative ${ }^{74}$ is too uniformly turbulent to cohere into a linear plot. ${ }^{75}$ Rather than

72 Prop. 4.1.135: haec tua castra, 137: militiam Veneris blandis patiere sub armis, 141-142: et bene cum fixum mento decusseris uncum,/nil erit hoc: rostro te premet ansa suo. Cf. DeBrohun 2003, 16sq.

73 Besides, as a sympathetic interlocutor incapable of understanding anything beyond the literal meaning of the poet's words, Horos resembles a similarly comic (and similarly 'Telchinian') character drawn in another Augustan programmatic poem - the jurist Trebatius who, in Horace's Satire 2.1, misinterprets the critique leveled at Horace for violating the generic laws of satire as a legal danger that the poet may face for violating the law of libel, the charge that, according to Trebatius, the poet could best avoid by composing encomia to Octavian. As I have shown elsewhere (Kirichenko, 2016, 217-226), Trebatius' literal-minded misinterpretation serves to draw attention to the extent to which Horace's Satires (most notably Satire 2.1 itself) are in fact informed by a profoundly encomiastic meaning.

74 This is indeed the main leitmotif of the Monobiblos (Book 1). See esp. Prop. 1.12.20: Cynthia prima fuit, Cynthia finis erit. Cf. Greene 1998, 37; Miller 2004, 6osq.

75 The only 'plot' that can plausibly be extracted from Books 1-3 is a story transition from youthful erotic excess to 'adulthood': Fear 2005; Wallis 2013, 229sq. Cf. Wyke 1987b, on Book 1 encouraging the illusion of Propertius documenting a real love story and Book 2 replacing that illusion with a purely meta-literary discourse. For a discussion of earlier 
tell a personal 'love story', this series of fragmented vignettes conjures up a cultural stereotype whose literary pedigree can be traced to New Comedy and Hellenistic epigram ${ }^{76}$ - an obsessive love for a 'hetaera' who is so desirable that she 'enslaves' her countless lovers, forcing them to cry patiently at her door while she entertains their rivals and to celebrate every rare night they get to spend with her as the pinnacle of human happiness. ${ }^{77}$ But while maintaining (and, in fact, enhancing) the basic parameters of this familiar scenario, Propertius uses it as a basis for a self-assertive metapoetic construct, so that his agonistic passion for Cynthia becomes indistinguishable from the process of gaining literary authority.

The docta puella that we encounter in Book 1 is not so much a mimetically credible representation of a human character as a dense intertextual image that subsumes countless literary prototypes with the express purpose to eclipse them all. ${ }^{78}$ In 1.2, Propertius praises Cynthia's 'natural' beauty and beseeches her to abstain from using any 'artificial' cosmetics (Prop. 1.2.1-14), but while presenting his own poetry as the only 'adornment' suitable for her, he simultaneously reveals that Cynthia's unadorned 'nature' can only be conceived of as a projection of countless images derived from Greek literature and art. ${ }^{79}$ Still more overtly, his girl's status as a work of art is emphasized in 1.3 where Propertius compares a sleeping Cynthia to a number of paradigmatic mythological figures (Ariadne, Andromeda, a Bacchante, and Io) and treats her immobile body as raw material for his own creative fantasy in that he effectively

attempts at biographical readings and a critique of such approaches, see Keith 2008, 86-114.

76 For a concise account of this literary background, see Sens 2011, xlii-xlviii. On Propertius and Hellenistic epigram, see Keith 2008, 45-51. On the influence of Hellenistic epigram on Roman love elegy in general, see contributions in Keith 2011. On connections between New Comedy and Roman love elegy, see Konstan 1994, 141-159.

77 On the Hellenistic background of elegiac paraklausithyra, see James 2003, 136. For the komos as a method appropriate only for courting a hetaera, not a marriageable girl, cf. Men. Dysc. 58-68. See also X. Mem. 3.11.13-18, where Socrates presents the tricks used by a hetaera to attract lovers as a kind of magic: Faraone 1999, 3sq. For interpretations of Propertius' Cynthia as a meretrix, see Miller 2004, 62.

78 On the impossibility to pinpoint the identity of Cynthia, who by turns appears to be a married matrona and a meretrix, a free woman and a slave, see Miller 2004, 61-63. On Cynthia in Book 1 as a "woman in a text' - a text that inscribes male desire and also reflects the self-conscious literary concerns of the poet", see Greene 1998, 37-66. Cf. Wyke $1987 \mathrm{~b}$ and $1989,28-34$.

79 The second half of the poem consists of a catalogue of 'naturally' attractive heroines of Greek myth (Prop. 1.2.15-20), known as such from Apelles' paintings (21-22), and the extended image of poetry as a girl's best adornment $\left(25^{-32}\right)$. On the "rhetoric of adornment" in Propertius and elsewhere, see Wyke 1994b. 
'molds' her image like an artist - crowning her with his garland, arranging her dishevelled hair, and putting apples in her slack hands (Prop. 1.3.19-24). ${ }^{80}$ Further poems of Book 1 not only reveal that Cynthia by far surpasses all those heroines of Greek literature and art that she resembles, ${ }^{81}$ but also point to her existential dependence on the poet's desire ${ }^{82}$ and, vice versa, to the poet's existential dependence on her presence. ${ }^{83}$ As a result, Cynthia becomes virtually synonymous with Propertius' love elegy, ${ }^{84}$ a Roman genre that seeks not only to appropriate but also to surpass a large segment of Greek cultural imaginary 85 and that, in the process, redefines the very essence of Roman culture. The most revealing witness of this thorough transformation is doubtless the venerable old door in 1.16, which used to welcome triumphal processions but is now reduced to being the sole addressee of the never-ending series of pitiful elegiac paraklausithyra. ${ }^{86}$

Within this metaliterary framework, the poet's single-minded determination to pursue his agonistic struggle for Cynthia, who promises endless bliss to multiple admirers while demanding absolute fidelity from each of them, ${ }^{87}$ becomes understandable in terms of literary rivalry 88 - as a struggle for the dominance over the literary landscape and, ultimately, as a struggle for poetic immortality. Propertius stages this struggle by positioning his poetry vis-à-vis other contemporary literary productions. His contrast between heroic epic and love elegy

8o For a detailed discussion of this poem's allusions to contemporary pictorial representations, see Valladares 2005, esp. 227 (on Prop. 1.3.19-24). See also Greene 1995, on Cynthia as a projection of male voyeuristic fantasies. On the (inter-)textuality of the poem's two speakers in 1.3 (the second one being Cynthia herself who wakes up to deliver a monologue reminiscent of Ariadne's speech in Catullus 64: i.e. she counters the male beholder's barrage of cultural fantasies with yet another cultural fantasy), see Zetzel 1996, 86-91.

81 E.g. Prop. 1.4.5-10 (Cynthia's beauty is superior to that of Greek mythical heroines); 1.5.7-8 (Cynthia is beyond comparison). Cf. 1.13.29-32.

82 Cf. Prop. 1.4.25-28: non ullo gravius temptatur Cynthia damno/quam sibi cum rapto cessat amore deus:/praecipue nostri. maneat sic semper, adoro,/nec quicquam ex illa quod querar inveniam!

83 Cf. Prop. 1.12 (on Cynthia's absence lamented in 1.11), esp. 11-12: non sum ego qui fueram, etc. On the mutual dependence between Propertius and Cynthia, cf. Greene 2005, 63sq.

84 Cf. Kennedy 1993, 5osq.; Wyke 1989, 33; Miller 2004, 63-66.

85 See also the notion that the words of the elegiac puella can overpower Jupiter at 1.13.32: illa suis verbis cogat amare Iovem.

86 Prop. 1.16.1-2: quae fueram magnis olim patefacta triumphis,/ianua Tarpeiae nota pudicitiae, etc. and 47-48: sic ego nunc dominae vitiis et semper amantis/fletibus aeterna differor invidia.

87 Cf. Prop. 1.5.25-26 and 1.15, esp. 32: sis quodcumque voles, non aliena tamen. On Cynthia encoding 'homosocial' relationships between men, see Miller 2004, 67sq., with references.

88 Quite revealingly, in 1.11 Propertius is jealous of a rival stealing Cynthia from his songs: an te nescio quis simulatis ignibus hostis/sustulit e nostris, Cynthia, carminibus? (7-8). 
allows him to redefine the servitium amoris (Roman poetry's enslavement to a collective cultural fantasy?) as the militia amoris - a strenuous military service that, to a contemporary poet, guarantees a surer passage to the Achillean 'undying fame' than would yet another imitation of the Homeric model..$^{89}$

In his intertextual dialogue with Gallus, too, Propertius seeks to replace the older poet as Rome's preeminent love elegist. ${ }^{90}$ Although in 1.10 he explicitly acknowledges Gallus as the main inspiration behind his own erotic poetry, ${ }^{91}$ Propertius stresses that what he gives back is in fact much more than he owes, ${ }^{92}$ and he flaunts his superior poetic power by implicitly contrasting, in 1.8, the rhetorical success of his own erotic poetry with Gallus' plaintive acquiescence to his inability to persuade his beloved ${ }^{93}$ and by making, in 1.18, a recognizably Gallan landscape resonate with Cynthia's name. ${ }^{94}$ As a consequence, Propertius presents himself as 'conquering' the territory of Roman love elegy with the same single-minded resolve with which he seeks to subject to Cynthia

89 See esp. the contrast between epic and elegy in 1.7 and 1.9: in 1.7, while Ponticus vies with Homer (3) Propertius derives his fame from Cynthia (haec mea fama est/hinc cupio nomen carminis ire mei, 9-10), but in 1.9 Ponticus, too, succumbs to 'love', i.e. begins to write love poetry. Cf. Stahl 1985, 48-71; Greene 1998, 47-51; Coutelle 2005, 144-158.

90 For a detailed discussion of Gallus in Propertius 1 in general, see Cairns 2006, 70-249, esp. 77 sq., on the scholarly dispute surrounding the identity of Propertius' 'Gallus'. Cf. Janan 2001, 33-52; Miller 2004, 68-83.

91 Prop. 1.10.1-10. Propertius' account of watching Gallus have sex with his puella would indeed make the best sense if understood as Propertius reading Gallus: Cairns 2006, 116 sq., with references.

92 Prop. 1.10.14sqq.: est quiddam in nobis maius, amice, fide, etc.: Cairns 2006, 117.

93 The extent of Propertius' evocation of Gallus in this poem can only be indirectly surmised on the basis of Virgil's Eclogue 10, where Gallus is portrayed as 'dying of love' for Lycoris who has left him to accompany her new lover on a military campaign. Cf. esp. Verg. Ecl. 10.22-23: tua cura Lycoris/perque nives alium perque horrida castra secuta est, 45-49, esp. 49: a, tibi ne teneras glacies secet aspera plantas! and Prop. 1.8.1-8, esp. 7-8: tu pedibus teneris positas fulcire pruinas,/tu potes insolitas, Cynthia, ferre nives? The second half of the poem (27-46) shows that Propertius' begging, unlike Gallus', has worked: vicimus:/assiduas non tulit illa preces (28): Cairns 2006, 114. Cf. Coutelle 2005, 163-165.

94 This 'Gallan' landscape is, again, the landscape in which Virgil's Gallus is 'perishing' in Eclogue 10. Cf. esp. Verg. Ecl. 10.52-54: certum est in silvis inter spelaea ferarum/ malle pati tenerisque meos incidere amores/arboribus: crescent illae, crescetis, amores and Prop. 1.18.19-22: vos eritis testes, si quos habet arbor amores,/fagus (a conspicuously Virgilian - Gallan? - tree: Ecl.1.1) et Arcadio pinus amica deo (cf. Verg. Ecl.10.14-15: pinifer ... Maenalus and 26: Pan deus Arcadiae)/a quotiens teneras resonant mea verba sub umbras (cf. Verg. Ecl.1.4-5: tu, Tityre, lentus in umbra/formosam resonare doces Amaryllida silvas),/ scribitur et vestris Cynthia corticibus! This Virgilian/'Gallan' landscape is not only overwritten (scribitur), but will also 'resound' (again cf. Verg. Ecl. 1.4-5), with Cynthia's name: 1.18.31-32: sed qualiscumque es, resonent mihi 'Cynthia' silvae,/nec deserta tuo nomine saxa vacent: Cairns 2006, 119sq. 
the entire totality of erotically enticing images of Greek culture. Cynthia herself emerges in turn as an icon of Propertius' poetic immortality - the poet and his creation destined to be forever inseparable as a work of poetic art. ${ }^{95}$

All these themes continue to dominate Book 2 of Propertius' elegies as well, where Cynthia is explicitly showcased as a miraculous creation de nihilo (2.1.17) whose effect is predicted to be as lasting as that of the Iliad (2.1.14) ${ }^{96}$ Since Cynthia's status as a literary symbol has by now been firmly established (she is said to be immensely popular throughout Rome), ${ }^{97}$ Propertius begins to draw a line between his undivided passion for Cynthia's poetic fame and immortality ${ }^{98}$ and the more conventional understanding of erotic desire: in 2.22, he suddenly confesses that, contrary to what we have become accustomed to assume, he in fact loves many girls, ${ }^{99}$ and in 2.23 he adopts a tone reminiscent of Horace's Satires in order to debunk the literal understanding of the elevated elegiac concept of servitium amoris by contrasting the sexual frustration suffered by an exclusus amator with the easy 'love' purchased from Oriental (slave-)prostitutes. ${ }^{100}$

But while Cynthia gradually ceases to function as an embodiment of physical sex appeal, there gradually emerges a homology between Cynthia as a

95 In 1.17, the fear of dying in a shipwreck (= disappearing without a trace; cf. Hor. Carm. 1.28) leads to Propertius wishing for Cynthia to bury him and to keep proclaiming his name after death: 23-24. Still more emphatically, the fear of death can only be alleviated in 1.19 by the prospect of Cynthia's posthumous love (sed ne forte tuo careat mihi funus amore, 3 ) and of the poet himself becoming an image of Cynthia (illic quidquid ero, semper tua dicar imago:/traicit et fati litora magnus amor, 11-12). On death in Propertius, see Papanghelis 1987.

96 See Greene 2005, on the equation between the puella and the poet's ingenium in 2.1. Cf. Wyke 1987b.

97 Prop. 2.24.1-2: 'tu loqueris, cum sis iam noto fabula libro/et tua sit toto Cynthia lecta foro?' Note, too, that the poet's indignation in 2.5 with the fact that Cynthia's 'misconduct' is known throughout Rome (hoc verum est, tota te ferri, Cynthia, Roma,/et non ignota vivere nequitia? 2.5.1-2) serves to unmask her beauty as a purely 'verbal' construct: scribam igitur, quod non umquam tua deleat aetas: 'Cynthia, forma potens: Cynthia, verba levis (27-28).

98 See e.g. Prop. 2.3.29-32: gloria Romanis una es tu nata puellis:/Romana accumbe [n]s prima puella Iovi,/nec semper nobiscum humana cubilia vises;/post Helenam haec terris forma secunda redit. Cf. 2.8, 2.14, 2.15, 2.27, and 2.34, esp. 93-94.

99 Prop. 2.22, esp. 13: quaeris, Demophoon, cur sim tam mollis in omnis. He then continues to brag about his sexual prowess (saepe est experta puella/officium tota nocte valere meum, 23-24) and to stress that one girl is simply not enough for someone like him (sic etiam nobis una puella parum est, 36$)$.

100 Prop. 2.23.21-24: et quas Euphrates et quas mihi misit Orontes,/me iuverint: nolim furta pudica tori./libertas quoniam nulli iam restat amanti,/nullus liber erit, si quis amare volet. Cf. Hor. S. 1.2, esp. 116-118. 
metaliterary construct and the political space of Augustus' empire - a territory that Propertius, now a member of Maecenas' circle, cannot afford to leave uncharted. ${ }^{101}$ In 2.10, the 'writing' of the ever-elusive 'girl', who effortlessly subsumes and surpasses all erotically enticing images of Greek culture, is declared to be over (quando scripta puella mea est, Prop. 2.10.8), and her evanescent image now imperceptibly morphs into the ever-retreating boundaries of empire that Augustus effortlessly brings under his control (cf. esp. si qua extremis tellus se subtrahit oris, 17) as well as into the impossible task of praising Augustus' striking achievements - a task that Propertius fearlessly undertakes nonetheless (cf. esp. quod si deficiant vires, audacia certe/laus erit, $5^{-6}$ ). ${ }^{102}$ Similarly, Augustus' imperial rule and Cynthia's popularity in Rome begin to appear as two conceptually coextensive notions when, in 2.31, Propertius comes late to a rendezvous with his mistress because he has been held back by the striking imagery of the newly opened temple of Apollo on the Palatine, the principal monument to Augustus regaining control over all of empire, ${ }^{103}$ and when, in 2.32, Cynthia ('Cynthia'?) is said to be free to visit any temple in Rome, her ubiquity enabling her to conquer the imagination of every Roman. ${ }^{104}$

The status of Propertius' literary project as a kind of iconic 'enactment' of Augustus' empire-building becomes still more pronounced in Book 3. Echoing the tone and the imagery of Horace's poetic manifesto in Carmen 3.30 (exegi monumentum), ${ }^{105}$ in 3.1 Propertius conceives of his introduction to Rome of

101 See Cairns 2006, 250-294. On Maecenas in Propertius 2.1, see Greene 2005, 67-76, esp. 76: "The image of the puella, it seems, merely provides the means through which one man may pay tribute to another."

102 Wyke 1987b, 49-53, esp. 53: "The narrative trajectory is from a male writer to a male reader, in which bella and a puella simply demarcate the boundaries between modes of discourse." Cf. Keith 2008, 115-138. See also Lyne 1998, on the possibility that the pair 2.10/2.11 stood at the end of the original Book 2a. Note, however, that the farewell to Cynthia, 2.11.1: scribant de te alii, sounds as much like a typical recusatio (cf. Hor. Carm. 1.6.: scriberis Vario) as does 2.10, and, as is generally the case with Augustan recusationes, both are followed by more poetry on the subjects the poet ostensibly refuses to handle. See also Miller 2004, 146-157, on the "homology of the Augustan and elegiac subject positions".

103 On Propertius 2.31 as "our principal guide" to "this grand temple", see Miller 2009, 196-206. On 2.31 as evidence of Propertius' "devotion to the regime", see Cairns 2006, 269sq. For a 'depoliticizing' reading of 2.31, see Welch 2005, 89-95.

104 Prop. 2.32.1-16 (Propertius is jealous because Cynthia is seen by so many men) and 61-62: quod si tu Graias es tuque imitata Latinas [sc. heroines of Greek myth, Roman legend, and Catullus' Lesbia],/semper vive meo libera iudicio! Propertius' 'liberation' (= publication) of 'Cynthia' finds a distinct parallel in Horace's liberating' his liber in Ep. 1.20: Kirichenko 2016, 226-232.

105 Cf. Prop. 3.1.3-4: primus ego ingredior puro de fonte sacerdos/Itala per Graios orgia ferre choros and Hor. Carm. 3.30.13-14. 
the elegiac poetry inspired by Callimachus and Philitas as a triumphal procession - the first step on the way to a poetic immortality comparable to that granted by Homeric poetry. ${ }^{106}$ After singling out, in 3.2, his poetic 'girl' as the sole object of his memorialization and after echoing, in 3.3, the prologue to Callimachus' Aetia in order to reject the composition of Ennian-style glorifications of Rome in favour of light-hearted love poetry, ${ }^{107}$ he soars, in 3.4, into an ecstatic vision of Augustus' triumph over Parthia, which now effectively merges with Propertius' own poetic triumph celebrated in 3.1. ${ }^{108}$ What further enhances the sense of fusion between these two triumphs is the fact that the poet now pictures himself embracing his 'girl' as he reads to her an endless list of captured cities. ${ }^{109}$

In a similar vein, Propertius begins his address to Maecenas in 3.9 by declaring his 'Callimachean' talent to be unsuitable for singing of grand epic themes (non sunt apta meae grandia vela rati, 4 ). But at the same time, he establishes a comprehensive analogy between his own poetic persona and the ethical ideal embodied by Maecenas - a conjunction that allows him to envisage the possibility of surpassing the limitations imposed on him by his 'slender' poetic 'nature': just as Maecenas' modesty conceals an almost epic authority (21-34), so Propertius, too, is now prepared to live up to his patron's call (te duce, 47) to immortalize the greatest events of Roman history as well as Augustus' contemporary conquests $\left(47^{-56}\right) .{ }^{110}$

While erotic themes do not completely disappear from Book 3 , love as an excruciating longing for an ever-retreating object of desire gradually gives way to a marriage-like arrangement governed by laws and mutually satisfactory agreements ${ }^{111}$ and finally, in 3.21, is given up completely in favour of the inner

106 Prop. 3.1.10: ... Musa triumphat ...; 25-34 (Troy owes its immortality to Homer, and Homer to his poem of Troy); 35-36: meque inter seros laudabit Roma nepotes:/illum post cineres auguror ipse diem. On the Callimachean substratum of Propertius 3.1, see Hunter 2006, 7-16.

107 Prop. 3.2.17-18: fortunata, meo si qua est celebrata libello!/carmina erunt formae tot monumenta tuae - a monument more lasting than the Pyramids, etc. and one granting immortality to the poet (19-26, cf. Hor. Carm. 3.30.1-7). For a detailed recent study of Propertius' Callimachean/Ennian dream in 3.3, see Scioli 2015, 134-172. Cf. Coutelle 2005, 500-507.

108 Cf. Prop. 3.1.9-12: quo me Fama levat terra sublimis, et a me/nata coronatis Musa triumphat equis,/et mecum in curru parvi vectantur Amores,/scriptorumque meas turba secuta rotas; 3.4.3: parat ultima terra triumphos ...; 13-14: [sc. dies] qua videam, spoliis onerato $[s]$ Caesaris axe $[s] /$ ad vulgi plausus saepe resistere equos.

109 Prop. 3.4.15-16: inque sinu carae nixus spectare puellae/incipiam et titulis oppida capta legam.

110 Cf. Cairns 2006, 267-269. On Maecenas' 'exemplarity' in this poem, see also Gazich 1995, 127-132.

111 Prop. 3.20.21-30, dominated by the vocabulary of legal obligation: foedus, fides, etc. 
poise granted by the study of Greek literature and philosophy. ${ }^{112}$ And while redirecting his eroticized longing from chasing the infinitely elusive intertextual 'girl' to the noble task of glorifying Augustus' control over the infinitely vast empire, ${ }^{113}$ Propertius begins to distance himself from the madness of elegiac love by projecting it onto the defeated enemies of Rome - Marc Antony implicitly cast in 3.11 as a typical elegiac lover forfeiting his Roman masculinity to Cleopatra, who in turn emerges as a larger-than-life version of Cynthia, vulgarized as a crazed whore threatening to enslave the entire male world of Rome. ${ }^{114}$ As a result, the misguided futility of elegiac desire retrospectively marks it off as an effeminate and/or infantile emotion sharply contrasted with the sure masculinity radiated by Augustus' imperial rule. ${ }^{115}$ At the end of the book, Propertius echoes Augustus' 'imperiousness' in that he, as it were, kills his Cynthia twice - by laying bare, in 3.24, her status as an empty cipher consisting of nothing but projections of Greek poetic stereotypes and by declaring, in 3.25 , her heretofore immortal beauty to be susceptible to ageing and death. ${ }^{116}$ What is more, in 3.22 he fills the void (about to be) left behind by Cynthia's evanescent phantom with a rapturous image of Italy. ${ }^{117}$ Italy is conceptualized here more or less in the same manner as Cynthia was in Book 1 - as a composite notion that subsumes and surpasses all wonders of Greek mythology.118 But in contrast to the tantalizing Cynthia whom Propertius has emphatically

112 Cf. Clarke 2004. See also O'Neill 2005, 255-257.

113 In Book 3 , 'love' also gradually gives way to imperial triumphs - e.g. in 3.12, where Postumus abandons his wife Galla (her faithfulness surpassing that of Penelope!) to follow Augustus on his imperial conquests.

114 Propertius draws a parallel between his enslavement to Cynthia and an entire catalogue of precedents from myth and history (3.11.1-26), which culminates in the image of Marc Antony enslaved by Cleopatra: quid modo qui nostris opprobria nexerit armis/et (famulos inter femina trita suos!)/coniugis obsceni pretium Romana poposcit/moenia et addictos in sua regna Patres (29-32); meretrix regina (39); quid nunc Tarquinii fractas iuvat esse securis .../si mulier patienda fuit? (47-49).

115 On the feminine persona of the elegiac lover, see Greene 2005, 61sq., with references. On the elegiac lover as a "youthful Roman elite male", on the fundamental (as it were, 'systemic') effeminacy of "all Roman youths", the contrast between elegiac effeminacy and the masculinity of Augustan ideology, and the attainment of notional adulthood at the end of Propertius 3, see Fear 2005. Cf. Wyke 1994a.

116 Prop. 3.24.1: falsa est ista tuae, mulier, fiducia formae, 5-6: mixtam te varia laudavi saepe figura,/ut, quod non esses, esse putaret amor and 3.25.31-34. On the issue of unity of 3.24/3.25, see Heyworth 2007, 412. Cf. Wallis 2013, 235sq. See also O'Neill 2005, 257-259. On Cynthia's ageing, see Gardner 2013, 207sq.

117 For a list of parallels between 3.21 and Virgil's laudes Italiae in the Georgics, see Heyworth and Morwood 2011, 315sq.

118 Prop. 3.22.17-18: omnia Romanae cedent miracula terrae/natura hic posuit, quidquid ubique fuit. Italy is a land of beautiful lakes and rivers, and it by far surpasses those countries that 
deprived of any extra-textual reality, Italy is not only real but is also cast as a safe retreat promising the stability of marriage rather than the pain caused by the excruciating elegiac desire. ${ }^{119}$

Book 4 makes more explicit the (dis-)analogy between erotic desire and poetic empire-building that has begun to take shape in the previous books: Propertius continues to project the basic template underlying the textual construct of Cynthia onto the political space of empire, to demystify Cynthia as a literal object of erotic longing, and to contrast unmanly elegiac desire with masculine self-control and imperial domination. But what Propertius additionally does in Book 4 is to postulate, much more emphatically than in the previous books, an intricate conjunction between erotic desire and imperial conquest and to translate this conjunction into broadly aetiological terms.

The image of Rome conjured up in 4.1 as a cultural void transformed into a locus of imperial plenitude is echoed in 4.2, where the Etruscan god Vertumnus, once a shapeless piece of wood but now an elaborately wrought statue that can be dressed to look like virtually anything one can imagine, ${ }^{120}$ is cast as an empty cipher, whose meaning, not unlike that of Cynthia in Book 1, is derived exclusively from the extraneous images that one chooses to project onto it. ${ }^{121}$ In a similar vein, the aetiological account of the temple of Jupiter Feretrius in 4.10 casts Rome as a place whose identity is derived exclusively from imperial conquests - as an empty receptacle of the three sets of spolia opima that commemorate the expansion of the imperial territory from the city's borders to Etruria and ultimately to Gaul. ${ }^{122}$

By contrast with the emphasis on endless flexibility and spatial expansiveness in some of the topographic poems, Propertius' allusions to the erotic themes of Books 1-3 retrospectively endow his love elegy with a sense of

produced such mythological monstrosities as Andromeda chained to a rock, Thyestes devouring his own children, etc.: $3.22 .23-36$.

119 Prop. 3.22.39-42: haec tibi, Tulle, parens, haec est pulcherrima sedes,/hic tibi pro digna gente petendus honos,/hic tibi ad eloquium cives, hic ampla nepotum/spes et venturae coniugis aptus amor. Cf. Cairns 2006, 353sq.

120 Prop. 4.2.21sqq.: opportuna mea est cunctis natura figuris:/in quamcumque voles verte, decorus ero, etc. Cf. Welch 2005, 35-55.

121 Cf. Edwards 1996, 55 .

122 Prop. 4.10.45-48: Edwards 1996, 54. For a very detailed 'subversive' reading of this poem, see Welch 2005, 133-165. 
total completeness and closure. In 4.5, Cynthia's perpetual elusiveness, which in the previous books has been presented as a function of her status as a poetic fantasy, is entirely reduced to a single remarkably trivial cause - to the instructions whereby the procuress used to urge the girl to admit only wealthy admirers, spurning the poet and his immaterial gifts. ${ }^{123}$ But although the poet now seems to celebrate the procuress's death by urging every 'lover' to throw stones on her grave (4.5.77-88), the disappearance of what now emerges as the sole obstacle on the way to erotic fulfilment simultaneously turns Propertius' love elegy, which could only thrive on unsatisfiable erotic longings, into a thing of impossibility. ${ }^{124}$

In 4.7, Cynthia herself is dead too, but, rather than an ever-retreating object of desire, the soliloquy she delivers from her grave reveals her to be a partial analogue of Cornelia, a model Roman matron who likewise speaks from the dead in 4.11: ${ }^{125}$ like Cornelia, Cynthia portrays herself as a faithful 'wife,',26 but in contrast to Cornelia, she complains about having received from her wayward 'husband' no decent funeral (27-32), but only 'verses written in my name' (quoscumque meo fecisti nomine versus, 77), which she now asks him to burn but which, as we know full well, will grant immortality both to Cynthia herself and to whomever else Propertius has chosen to mention in his poetry. ${ }^{127}$

Finally, the fact that, in 4.8, Cynthia turns out to be still very much alive (the story told by Propertius happened 'last night': hac nocte, 4.8.1) serves to corroborate her fictional status. ${ }^{128}$ But the character we encounter in this poem has nothing to do with the Cynthia that we got to know in the first three books. In lieu of the excruciating drama of erotic enslavement, we are now confronted

\footnotetext{
123 Prop. 4.5.21-62. Cf. Myers 1996.

124 On the centrality of absence/separation for the functioning of Propertius' love elegy, see Walde 2008 .

125 Cairns 2006, 358-361. For a sophisticated analysis of Cornelia as an Augustan exemplum, see Lowrie 2008. For a reading sensitive to the fissures in the poem's 'Augustanism', see Janan 2001, 146-163.

126 Needless to say, Cynthia having sex with her lover on the streets of Saburra (4.7.15-20) is a far cry from Cornelia's matronly virtues. But at the same time, she presents herself as no less faithful than Cornelia: iuro ... me servasse fidem (4.7.51-53; cf. esp. 4.7.53-54: si fallo, vipera nostris/sibilet in tumulis et super ossa cubet and 4.11.27-28: si fallo [r], poena sororum/infelix umeros urgeat urna meos), residing now in the portion of the underworld reserved for such virtuous heroines as Andromeda and Hypermestra: 4.7.63-70. On "Cynthia's truth", see Janan 2001, 100-113.

127 Cf. Prop. 4.7.93-94: nunc te possideant aliae: mox sola tenebo:/mecum eris et mixtis ossibus ossa teram. As in Books 1-3, Propertius' postmortem existence is inseparable from Cynthia.

128 Hutchinson 2006, 189 .
} 
with a version of a droll adultery mime featuring a (for all we know, faithful) ${ }^{129}$ woman who safely returns from an archaic chthonic ritual (which serves to test young girls' chastity) ${ }^{130}$ to find her boyfriend sandwiched between two drunken prostitutes (inter utramque fui, 36 ) - a situation that she efficiently resolves by chasing away her rivals (57-62), by imposing on Propertius the 'law' of fidelity (73-82, esp. formula legis, 74, and legibus utar, 81), by ritually purifying the room (83-86), and by reclaiming her rightful place in his bed $(87-88) \cdot{ }^{131}$

While 4.8 conceives of male erotic desire as a purely physical urge that can be restrained (however provisionally) by a pragmatic marriage-like arrangement, elegiac love as a longing for the absent and/or unattainable is relegated in Book 4 into the domain of female sexuality. ${ }^{132}$ What is more, this desire is, more overtly than in the previous books, marked as a fundamentally imperial impulse. In 4.4, Tarpeia, a Vestal virgin inhabiting the original bucolic landscape of Rome that, as in 4.1, is devoid of cultural images, ${ }^{133}$ is willing to betray her uncivilized country because she is attracted to the artfully wrought armour (picta ... arma, 4.4.20) worn by Rome's enemy, the Sabine king Tatius. ${ }^{134}$ Tarpeia's maddening desire turns Rome's attraction to things foreign into the originary force behind its imperial identity. ${ }^{135}$ But the fact that Tatius, the object of Tarpeia's unpatriotic desire, kills her with the foreign arms she has found so irresistible ${ }^{136}$ simultaneously reveals the unsettling contradiction between Rome's 'pure' origins and its all-consuming imperialism - the temple

129 Propertius' fantasy of Cynthia's trip to Lanuvium as a pretext for an erotic adventure (causa fuit Iuno, sed mage causa Venus, etc., 4.8.16-26) sounds in context like a recycled reflection of his jealous fantasies in the earlier books, e.g. in 1.11 or especially 2.32 , where Cynthia also travels to Lanuvium (2.32.6). Cf. Greene 1998, 59-66.

130 Prop. 4.8.3-14. On the cult at Lanuvium, see Hutchinson 2006, 191sq., with references.

131 Janan 2001, 114-127. On Cynthia's jealousy, see Caston 2012, 98-100.

132 On the female perspectives in Book 4 in general, see Wyke $1987 \mathrm{a}$.

133 Cf. Prop. 4.4.1-14 and 4.1.1-38. What is more, Tarpeia's attempt to betray Rome to a foreigner takes place during the Parilia (4.4.73-78) - singled out at 4.1.19 as one of the most salient manifestations of the original Roman religion that did not worship foreign gods.

134 Prop. 4.4.19-21: vidit harenosis Tatium proludere campis/pictaque per flavas arma levare iubas:/obstipuit regis facie et regalibus armis. Note that almost in all other literary versions of the Tarpeia story her motivation for betraying Rome is said to be greed rather than love: Miller 2004, 189-192; Welch 2005, 56; Hutchinson 2006, 116-119.

135 Of course, the Romans and the Sabines subsequently merge into a single state (Livy 1.1113, esp. 1.13.4: regnum consociant: imperium omne conferunt Romam; ironically enough, Propertius' Tarpeia envisages the same scenario taking place under the lead of the Sabines: 4.4.55-62), so that Tarpeia emerges as a symbol not only of treason but also of Rome "absorb[ing] her former enemies completely" (Janan 2001, 75) - and thus a symbol of imperial expansion. Cf. Welch 2005, 57 .

136 Prop. 4.4.91: ingestis comitum super obruit armis. 
of Jupiter Capitolinus on the Tarpeian rock commemorating what now looks like a (tragic) aetiology of that fundamental contradiction. ${ }^{137}$

The aetiological import of Propertius' version of the Tarpeia story becomes particularly revealing if the poem is read alongside 4.3 . In stark contrast to 4.4 's portrayal of Tarpeia's love for an enemy, 4.3 presents the tension between the (conceptually empty) purity of Rome and the (spatially remote) plenitude of empire in terms of marriage. To Arethusa, the perpetual absence of her husband Lycotas always conquering new territories at the increasingly distant edges of the world turns Rome itself into an empty place devoid of meaning, 138 so that she can only alleviate her longing for the absent by means of symbolic substitutes (a map of the empire over which she obsessively pores ${ }^{139}$ and her husband's weapons that she kisses in lieu of his body $)^{140}$ as well as by entertaining the (doubtless illusory) hope that he will triumph only over foreign countries rather than foreign women. ${ }^{141}$ Far from being a model of conjugal

137 See Miller 2004, 192-195, on Tarpeia's nature as "the coincidentia oppositorum".

138 While he is fighting in Parthia, Thrace, Britain, or India (4.3.7-10), she feels close to death (11-16) and wishes she could, like an Amazon, join him in battle (43-48) instead of being confined to Rome, where, without him, it feels meaningless to wear expensive clothes and jewelry (51-52) and where omnia surda tacent (53), etc. See Janan 2001, 54. There are multiple revealing (dis-) analogies between Arethusa longing for Lyco-tas and Gallus longing for Lyco-ris in Virgil's Eclogue 10 (cf. esp. Prop. 4.3.23: dic mihi, num teneros urit lorica lacertos? and Verg. Ecl. 10.49: a, tibi ne teneras glacies secet aspera plantas!; note, too, that Arethusa's counterpart in 3.12, a poem that imagines exactly the same scenario as 4.3, is named Galla, see n. 114 above): ironically enough, the shift from the male elegiac desire for the ever-absent puella to the female view of the imperial marriage to an ever-absent man results for Arethusa in a futile longing not only for her husband, who eerily resembles an effeminate elegiac lover (teneros ... lacertos, 4.3.23, imbellis ... manus, 24; cf. Janan 2001, 58sq.), but also for the 'freedom of movement' enjoyed by the elegiac puella: cf. Verg. Ecl. 10.22-23: tua cura Lycoris/perque nives alium perque horrida castra secuta est and Prop. 4.3.45-48: Romanis utinam patuissent castra puellis!/essem militiae sarcina fida tuae,/nec me tardarent Scythiae iuga, cum Pater altas/acriter in glaciem frigore nectit aquas.

139 Prop. 4.3.37: cogor et e tabula pictos ediscere mundos. On the significance of Arethusa's map, see Janan 2001, 65-69.

140 Prop. 4.3.29-30: at mihi cum noctes induxit vesper amaras,/si qua relicta iacent, osculor arma tua.

141 Prop. 4.3.25-26: haec [sc. lorica and hasta] noceant potius quam dentibus ulla puella/det mihi plorandas per tua colla notas! and 67-69 sed (tua sic domitis Parthae telluris alumnis/ pura triumphantis hasta sequatur equos)/incorrupta mei conserva foedera lecti! Of course, pura hasta is a technical term for a headless spear awarded to a victorious soldier (see Hutchinson 2006, ad loc., with references), but in the context of Arethusa's urgent concern with her husband's sexual conduct (on hasta, among other elongated weapons, as a sexual metaphor, see Adams 1982, 19-22, as well as 199, on purus), one cannot help but feel reminded of Augustus calling Horace purissimum penem in Suetonius' Vita Horati. 
happiness, the 'proper' distribution between the gender roles within this imperial marriage (she desires while he conquers) functions as a metaphor for the irreducible discrepancy in Augustan culture between the desire for primordial simplicity (for the 'hill and grass' of 4.1 or the Vestal virgin's purity in 4.4) and the desire for universal domination, which ultimately equates Rome with the geographically vast and morally complex empire. ${ }^{142}$

It is hardly surprising that in his two most overtly imperial poems ( 4.6 and 4.9) Propertius glosses over this unsettling discrepancy and instead celebrates a notional fusion between the elegiac desire for the absent and the imperial desire for universal conquest. In 4.9, Propertius puts an elegiac spin on the myth of Hercules' victory over Cacus, which, as we have seen, Virgil recounts in Aeneid 8 as an aetiology of the ara maxima. In stark contrast to Virgil's paragon of epic heroism, Propertius' Hercules bears traits both of a Roman elegiac lover and of a Callimachean poet. Seized by thirst after his battle against Cacus, Hercules asks for water from the spring at the sanctuary of Bona Dea, strictly off-limits to men, delivering what sounds like a version of an elegiac paraklausithyron in which he ingratiates himself with women by citing his former 'elegiac' enslavement to the queen Omphale. ${ }^{143}$ It is highly significant, however, that, unlike an elegiac lover, Hercules desires not a woman but water from a very special spring: for on a closer look Propertius' framing of Hercules' thirst turns out to bundle multiple allusions to Callimachus into a powerful metapoetic gesture.

The most conspicuous among these allusions is the priestess' attempt to dissuade Hercules from penetrating into the female sanctuary by appealing to the myth, told in Callimachus' fifth Hymn, of Tiresias blinded by Athena because he, driven by thirst, approached a spring where the naked goddess happened to be bathing. ${ }^{144}$ Furthermore, Hercules' need to quench his thirst

142 Most revealing is the juxtaposition of the restoration of the old mores and the emphasis on universal conquest in Augustus' Res Gestae, esp. 3: bella terra et mari civilia externaque toto in orbe terrarum saepe gessi and 8: legibus novis me auctore latis multa exempla maiorum exolescentia iam ex nostro saeculo reduxi et ipse multarum rerum exempla imitanda posteris tradidi. On this tension, see e.g. Galinsky 1996, $58-77$.

143 Prop. 4.9.47-5o. Cf. 3.11.17-20, where Omphale, among other heroines of myth and history, is paralleled with Propertius' enslaving puella. On Hercules as an elegiac exclusus amator, see Anderson 1964; Pinotti 1977; Cairns 1992. On the function of elegiac 'liminality' in Book 4 as a whole, see DeBrohun 2003, 118-155, and 156-200, on the reverberations of Hercules' cross-dressing in the rest of the book. On Hercules' 'gender bender', see also Welch 2005, 120-131.

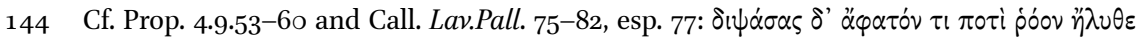
xpávas. On Callimachus' Tiresias myth, see Stephens 2015, 237sq. The conclusion of 4.9 also evokes a number of Callimachus' Hymns. Cf. Prop. 4.9.71-72: sancte pater salve, cui iam favet aspera Iuno:/Sanc $[t]$ e, velis libro dexter inesse meo and Call. Jov. 94: $\chi \alpha \hat{\rho} \rho \varepsilon \pi \dot{\alpha} \tau \varepsilon \rho$, 
at the sanctuary of Bona Dea is linked to 'the fertile/pregnant earth providing no water' (terraque non [n] ullas feta ministrat aquas, 4.9.22), which conjures up the image of the water-deprived Rhea begging the Earth in Callimachus'

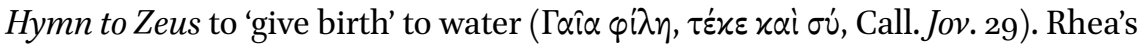
prayer is motivated in Callimachus by the fact that Arcadia, now so rich in

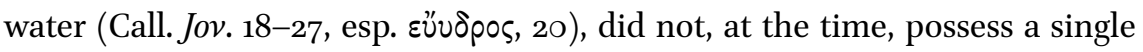
river! ${ }^{145}$ By contrast, Propertius' Hercules not only finds himself on a riverbank, but the pre-historic Tiber is also said to have carried so much more water than it currently does that the flooded Velabrum formed a veritable harbour. ${ }^{146}$ This discrepancy is highly meaningful. The fact that Hercules does not consider the possibility of drinking from the 'stagnating' river (stagnabant, Prop. 4.9.5), by which he is literally surrounded, but, instead, does everything in his power to obtain water from a forbidden spring located in an out-of-the-way sacred precinct distinctly evokes one of the most frequently imitated Callimachean passages - the conclusion of the Hymn to Apollo in which the god himself rejects poetry that resembles the muddy waters of 'the huge Assyrian river' and welcomes poetry similar to the pure water of a tiny spring sacred to a powerful goddess. ${ }^{147}$

Propertius' Hercules immediately abandons the stance of an incessantly pining elegiac 'lover' when his paraklausithyron is spurned by the priestess, and, without any further ado, he simply breaks into the sanctuary to quench his thirst, thereby regaining his heroic identity. ${ }^{148}$ As a result, Propertius' poem not only aetiologizes the ara maxima as a locus of Hercules' victory over women, who have 'ever since then' been forbidden to approach the altar, ${ }^{149}$ but also creates a monument to the 'elegiac' past of the greatest Greek hero, whose ability to feel 'elegiac' desire, paradoxically enough, turns out to be

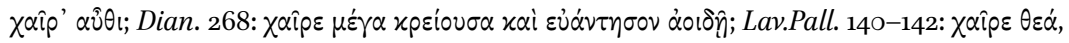
$\chi \tau \lambda$. Cf. Pinotti 1977, 53 .

145 Call. Jov. $18-27$ is a catalog of Arcadian rivers that did not exist yet when Rhea gave birth to Zeus.

146 Prop. 4.9.5-6: qua Velabra suo stagnabant flumine quaque/nauta per urbanas velificabat aquas.

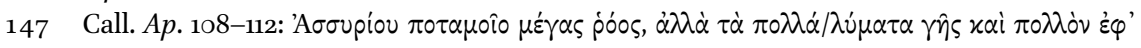

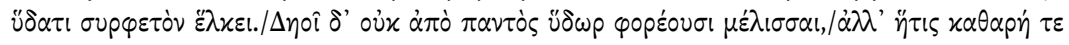

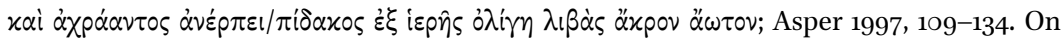
allusions to this passage in Augustan poetry in general and in Propertius in particular, see Wimmel 1960. Cf. esp. Prop. 3.1.3: puro de fonte.

148 Prop. 4.9.61-62: sic anus: ille umeris postis concussit opacos,/nec tulit iratam ianua clausa sitim. Note that Hercules' thirst has now become imbued with an epic ira $=$ the $\mu \eta v i \varsigma$ of the Iliad.

149 Prop. 4.9.69: haec nullis umquam pateat veneranda puellis. 
inextricably linked to his status not only as an adherent of Callimachean aesthetics but also as a conqueror of the entire world. ${ }^{150}$ By 'heroically' violating one of the most characteristic conventions of Roman love elegy in order to drink from a 'Callimachean' spring, Hercules reveals that Propertius' version of 'Callimachean poetics' may indeed consist in enacting a transformation of the elegiac desire for the unattainable into an act of heroic conquest.

This conjunction between elegiac desire and heroic conquest serves as a notional aetiology of Augustus' victory at Actium celebrated in 4.6.51 Like the ara maxima in 4.9, the temple of Apollo on the Palatine is presented in this poem as a commemoration of a victory over a woman (dat femina poenas, Prop. 4.6.57) physically banned from the 'sacred space' of Rome: Cleopatra is presented as so incompatible with Rome's masculine power that even by being paraded in a triumphal procession (something that her suicide had luckily averted) she would have defiled the city. ${ }^{152}$ The Apollo temple is cast in the poem as a token of a complete conceptual fusion between Rome and the empire that it finds itself in the never-ending process of conquering. The naval battle of Actium memorialized by the temple not only witnesses the gathering of the whole world (huc mundi coiere manus, 4.6.19) but also marks its subjugation to Augustus (vince mari: iam terra tua est, 4.6.39). What is more, the temple itself is not only a condensed image of this universal event transposed into the very heart of Rome, but also provides a venue for an imaginary competition among elegiac poets (cf. the habitual evocation of Callimachus and Philitas at 4.6.1-4) whose songs give expression to the ever-insatiable longing for the remotest edges of the empire already subservient to Rome or still waiting to be subdued in the future. ${ }^{153}$

By staging a conjunction between the elegiac longing for an ever-retreating object and the never-ending imperial expansion, Propertius reveals that the semblance of a secure control over empire by no means cancels out the desire for the increasingly more unreachable. No amount of imperial plenitude can,

150 Prop. 4.9.73-74: hunc, quoniam manibus purgatum sanxerat orbem,/sic Sanc [t]um Tatiae composuere Cures.

151 Another important point of contact between 4.9 and 4.6 is that both of them are deeply indebted to Callimachus' Hymns. See Cairns 1984, 137-149, for an analysis of the 'hymnic' (and in particular Callimachean) features of 4.6. The most explicit reference to Callimachus is 4.6.27-28: cum Phoebus linquens stantem se vindice Delon/(nam tulit iratos mobilis un $[d]$ a Notos), which evokes the Hymn to Delos. On this poem, see also Kierdorf 1995; Miller 2009, 80-92.

152 Prop. 4.6.65-66: di melius! quantus mulier foret una triumphus,/ductus erat per quas ante Iugurtha vias!

153 Prop. 4.6.77-82. For a specimen of a 'subversive' reading of 4.6, see Welch 2005, 96-111, with references. 
in other words, fill the original emptiness of 4.1's bucolic 'hill and grass'. Far from suppressing the sense of tantalizing disquietude inherent in the image of imperium sine fine, Propertius presents the perpetual transformation of 'elegiac' desire into imperial conquest, the process that he enacts throughout his own poetic oeuvre, as a crucial mechanism of empire-building - as a kind of 'aetiology' of empire.

\section{Bibliography}

Acosta-Hughes, B., Lehnus, L. and Stephens, S., edd. (2011). Brill's Companion to Callimachus. Leiden/Boston: Brill.

Acosta-Hughes, B. and Stephens, S. (2012). Callimachus in Context. From Plato to the Augustan Poets. Cambridge: Cambridge University Press.

Adams, J. (1982). The Latin Sexual Vocabulary. London: Duckworth.

Ancona, R. and Greene, E., edd. (2005). Gendered Dynamics in Latin Love Poetry. Baltimore: John Hopkins University Press.

Anderson, W.S. (1964). Hercules exclusus. Propertius, IV, 9. American Journal of Philology, 85(1), pp. 1-12.

Asper, M. (1997). Onomata allotria. Zur Genese, Struktur und Funktion poetologischer Metaphern bei Kallimachos. Stuttgart: Franz Steiner.

Asper, M. (2001). Gruppen und Dichter. Zu Programmatik und Adressatenbezug bei Kallimachos. Antike und Abendland, 47, pp. 84-116.

Asper, M. (2011). Dimensions of Power. Callimachean Geopoetics and the Ptolemaic Empire. In: Acosta-Hughes/Lehnus/Stephens 2011, pp. 155-177.

Asper, M. (2013). Minding the Gap. Aetiology and (False) Closure. In: Grewing/ Acosta-Hughes/Kirichenko 2013, pp. 63-82.

Barbantani, S. (2002). Callimachus and the Contemporary Historical 'Epic'. Hermathena, 173-174, pp. 29-47.

Barchiesi, A. (1997). The Poet and the Prince. Ovid and Augustan Discourse. Berkeley: University of California Press.

Benedetto, G. (2011). Callimachus and the Atthidographers. In: Acosta-Hughes/Lehnus/ Stephens 2011, pp. 347-367.

Bing, P. (1988). The Well-Read Muse. Present and Past in Callimachus and in Hellenistic Poets. Göttingen: Vandenhoeck \& Ruprecht.

Bowie, E. (1986). Early Greek Elegy, Symposium and Public Festival. Journal of Hellenic Studies, 106, pp. 13-35.

Cairns, F. (1984). Propertius and the Battle of Actium (4.6). In: T. Woodman and D. West, edd., Poetry and Politics in the Age of Augustus. Cambridge: Cambridge University Press, pp. 129-168. 
Cairns, F. (1992). Propertius 4.9. Hercules exclusus and the Dimensions of Genre. In: K. Galinsky, ed., The Interpretation of Roman Poetry. Empiricism or Hermeneutics? Frankfurt am Main: Peter Lang, pp. 65-95.

Cairns, F. (2006). Sextus Propertius. The Augustan Elegist. Cambridge: Cambridge University Press.

Cameron, A. (1995). Callimachus and His Critics. Princeton: Princeton University Press.

Caston, R. (2012). The Elegiac Passion. Jealousy in Roman Love Elegy. Oxford/New York: Oxford University Press.

Clarke, J. (2004). 'Goodbye to All That'. Propertius' magnum iter between Elegies 3.16 and 3.21. Mouseion, 4(2), pp. 127-143.

Clayman, D. (2011). Berenice and Her Lock. Transactions of the American Philological Association, 141(2), pp. 229-246.

Corner, S. (2010). Transcendent Drinking. The Symposium at Sea Reconsidered. Classical Quarterly, 6o(2), pp. 352-380.

Coutelle, É. (2005). Poétique et métapoésie chez Properce. De l'ars amandi à l'ars scribendi. Leuven: Peeters.

DeBrohun, J. (2003). Roman Propertius and the Reinvention of Elegy. Ann Arbor: University of Michigan Press.

Dougherty, C. (1994). Archaic Greek Foundation Poetry. Questions of Genre and Occasion. Journal of Hellenic Studies, 114, pp. 35-46.

Edwards, E. (1996). Writing Rome. Textual Approaches to the City. Cambridge: Cambridge University Press.

Fantham, F. (1997). Images of the City. Propertius' New-Old Rome. In: T. Habinek and A. Schiesaro, edd., The Roman Cultural Revolution. Cambridge: Cambridge University Press, pp. 122-135.

Fantuzzi, M. and Hunter, R. (2004). Tradition and Innovation in Hellenistic Poetry. Cambridge: Cambridge University Press.

Faraone, C. (1999). Ancient Greek Love Magic. Cambridge, Mass.: Harvard University Press.

Fear, T. (2005). Propertian Closure. The Elegiac Inscription of the Liminal Male and Ideological Contestation in Augustan Rome. In: Ancona/Greene 2005, pp. 13-40.

Fuhrer, T. (1992). Die Auseinandersetzung mit den Chorlyrikern in den Epinikien des Kallimachos. Basel: Reinhardt.

Galinsky, K. (1996). Augustan Culture. An Interpretive Introduction. Princeton: Princeton University Press.

Gardner, H. (2013). Gendering Time in Augustan Love Poetry. Oxford: Oxford University Press.

Gazich, R. (1995). Exemplum ed esemplarità in Properzio. Milan: Vita e Pensiero.

Greene, E. (1995). Elegiac Woman. Fantasy, Materia and Male Desire in Propertius 1.3 and 1.11. American Journal of Philology, 116(2), pp. 303-318. 
Greene. E. (1998). The Erotics of Domination. Male Desire and the Mistress in Latin Love Poetry. Baltimore/London: John Hopkins University Press.

Greene, E. (2005). Gender Identity and the Elegiac Hero in Propertius 2.1. In: Ancona/ Greene 2005, pp. 61-77.

Grewing, F., Acosta-Hughes, B. and Kirichenko, A., edd. (2013). The Door Ajar. False Closure in Greek and Roman Literature and Art. Heidelberg: Winter.

Gutzwiller, K. (1992). Callimachus' Lock of Berenice. Fantasy, Romance, and Propaganda. American Journal of Philology, 113(3), pp. 359-385.

Habash, M. (1995). Two Complementary Festivals in Aristophanes' Acharnians. American Journal of Philology, 116(4), pp. 559-577.

Hamilton, R. (1992). Choes and Anthesteria. Athenian Iconography and Ritual. Ann Arbor: University of Michigan Press.

Harder, A. (2003). The Invention of Past, Present and Future in Callimachus' Aetia. Hermes, 131(3), pp. 290-306.

Harder, A. (2012). Callimachus. Aetia, vol. 1: Introduction, Text, and Translation, vol. 2: Commentary. Oxford: Oxford University Press.

Heyworth, S. (2007). Cynthia. A Companion to the Text of Propertius. Oxford: Oxford University Press.

Heyworth, S. and Morwood, J. (2011). A Commentary on Propertius, Book 3. Oxford: Oxford University Press.

Hobden, F. (2013). The Symposion in Ancient Greek Society and Thought. Cambridge: Cambridge University Press.

Hollis, A. (1992). The Nuptial Rite in Catullus 66 and Callimachus' Poetry for Berenice. Zeitschrift für Papyrologie und Epigraphik, 91, pp. 21-28.

Hunter, R. (2006). The Shadow of Callimachus. Studies in the Reception of Hellenistic Poetry in Rome. Cambridge: Cambridge University Press.

Hutchinson, G. (2006). Propertius. Elegies. Book IV. Cambridge: Cambridge University Press.

Jackson, S. (2001). Callimachus. Coma Berenices. Origins. Mnemosyne, 54(1), pp. 1-9.

James, S. (2003). Learned Girls and Male Persuasion. Gender and Reading in Roman Love Elegy. Berkeley: University of California Press.

Janan, M. (2001). The Politics of Desire. Propertius IV. Berkeley: University of California Press.

Keith, A. (2008). Propertius. Poet of Love and Leisure. London: Duckworth.

Keith, A., ed. (2011). Latin Elegy and Hellenistic Epigram. A Tale of Two Genres at Rome. Newcastle upon Tyne: Cambridge Scholars Publishing.

Kennedy, D. (1993). The Arts of Love. Five Studies in the Discourse of Roman Love Elegy. Cambridge: Cambridge University Press.

Kierdorf, W. (1995). Properzens Actium-Elegie (4.6). Künstlerische Bewältigung einer politischen Annäherung. In: G. Binder and B. Effe, edd., Affirmation und Kritik. Zur 
politischen Funktion von Kunst und Literatur im Altertum. Trier: Wissenschaftlicher Verlag Trier, pp. 165-184.

Kirichenko, A. (2010). Von Delphi nach Kyrene. Dichtung und Religion in Kallimachos' Hymnus auf Apollon. Wiener Studien, 123, pp. 37-61.

Kirichenko, A. (2013). Virgil's Augustan Temples. Image and Intertext in the Aeneid. Journal of Roman Studies, 103, pp. 65-87.

Kirichenko, A. (2016) Conviva satur: Mündlichkeit, Schriftlichkeit und Patronage in den sermones des Horaz. Poetica, 48(3-4), pp. 201-240.

Kirichenko, A. (2017). Longing for Alexandria (Call. Aetia, fr. 178Pf.). In: K. Coleman, ed., Albert's Anthology. Cambridge, Mass.: Harvard University Press, pp. 97-98.

Koenen, L. (1993). The Ptolemaic King as a Religious Figure. In: A. Bulloch, E. Gruen, A. Long and A. Stewart, edd., Images and Ideologies. Self-Definition in the Hellenistic World. Berkeley: University of California Press, pp. 25-115.

Konstan, D. (1994). Sexual Symmetry. Love in the Ancient Novel and Related Genres. Princeton: Princeton University Press.

Kowalzig, B. (2007). Singing for the Gods. Performances of Myth and Ritual in Archaic and Classical World. Oxford: Oxford University Press.

Liveley, G. and Salzman-Mitchell, P., edd. (2008). Latin Elegy and Narratology. Fragments of a Story. Columbus: Ohio State University Press.

Lowrie, M. (2008). Cornelia's Exemplum. Form and Ideology in Propertius 4.11. In: Liveley/Salzman-Mitchell 2008, pp. 180-195.

Ludwig, P. (2002). Eros and Polis. Desire and Community in Greek Political Theory. Cambridge: Cambridge University Press.

Lyne, R. (1998). Propertius 2.10 and 11 and the Structure of Books '2A' and '2B'. Journal of Roman Studies, 88, pp. 21-36.

Malkin, I. (2011). A Small Greek World. Networks in the Ancient Mediterranean. Oxford/ New York: Oxford University Press.

Männlein-Robert, I. (2010). Zwischen Musen und Mouseion, oder die poetische (Er-)Findung Griechenlands in den Aitien des Kallimachos. In: Weber, G., ed., Alexandreia und das ptolemäische Ägypten: Kulturbegegnungen in hellenistischer Zeit. Berlin: Verlag Antike, pp. 16o-186.

Maurizio, L. (2001) Performance, Hysteria, and Democratic Identities in the Anthesteria. Helios, 28(1), pp. 29-41.

Miller, J. (1982). Callimachus and the Augustan Aetiological Elegy. Aufstieg und Niedergang der römischen Welt, II 30.1, ed. W. Haase, Berlin/New York: De Gruyter, pp. $371-417$.

Miller, J. (2009). Apollo, Augustus, and the Poets. Cambridge: Cambridge University Press.

Miller, P. (2004). Subjecting Verses. Latin Love Elegy and the Emergence of the Real. Princeton: Princeton University Press. 
Morgan, L. (1998). Assimilation and Civil War. Hercules and Cacus. Aeneid 8. In: H.-P. Stahl, ed., Vergil's Aeneid. Augustan Epic and Political Context. London: Duckworth, pp. 175-197.

Murray, O., ed. (1990). Sympotica. A Symposium on the Symposion. Oxford: Clarendon Press.

Myers, K. (1996). The Poet and the Procuress. The Lena in Latin Love Elegy.Journal of Roman Studies, 86, 1-21.

O'Hara, J. (1996). True Names. Vergil and the Alexandrian Tradition of Etymological Wordplay. Ann Arbor: University of Michigan Press.

O'Neill, K. (2005). The Lover's Gaze and Cynthia's Glance. In: Ancona/Greene 2005, pp. $243^{-268 .}$

Papanghelis, T. (1987). Propertius. A Hellenistic Poet on Love and Death. Cambridge: Cambridge University Press.

Pinotti, P. (1977). Propert. IV 9. Alessandrinismo e arte allusiva. Giornale Italiano di Filologia, 29(1), pp. 50-71.

Prioux, E. (2011). Callimachus' Queens. In: Acosta-Hughes/Lehnus/Stephens 2011, pp. 201-224.

Reed, J. (2007). Virgil's Gaze. Nation and Poetry in the Aeneid. Princeton: Princeton University Press.

Rimell, V. (2015). The Closure of Space in Roman Poetics. Empire's Inward Turn. Cambridge: Cambridge University Press.

Rosokoki, A. (1995). Die Erigone des Eratosthenes. Eine kommentierte Ausgabe der Fragmente. Heidelberg: Winter.

Rothwell, K. (1996). Propertius on the Site of Rome. Latomus, 55(4), pp. 829-854.

Sbardella, L. (2000). Filita. Testimonianze e frammenti poetici. Introduzione, edizione e commento. Rome: Edizioni Quasar.

Schmitt Pantel, P. (1992). La cité au banquet. Histoire des repas publics dans les cités grecques. Rome: École Française de Rome.

Schmitz, T. (1999). 'I Hate All Common Things'. The Reader's Role in Callimachus' Aetia Prologue. Harvard Studies in Classical Philology, 99, pp. 151-178.

Scholtz, A. (2007). Concordia discors. Eros and Dialogue in Classical Athenian Literature. Washington, D.C.: Center for Hellenic Studies.

Schwinge, E.-R. (1986) Künstlichkeit von Kunst: Zur Geschichtlichkeit der alexandrinischen Poesie. Munich: Beck.

Scioli, E. (2015). Dream, Fantasy, and Visual Art in Roman Elegy. Madison: University of Wisconsin Press.

Scodel, R. (1980). Wine, Water, and the Anthesteria in Callimachus Fr. 178 Pf. Zeitschrift für Papyrologie und Epigraphik, 39, pp. 37-40.

Selden, D. (1998). Alibis. Classical Antiquity, 17(2), pp. 289-412. 
Sens, A. (2011). Asclepiades of Samos. Epigrams and Fragments. Oxford: Oxford University Press.

Sistakou, E. (2008). Beyond the Argonautica. In Search of Apollonius' Ktisis Poems. In: T.D. Papanghelis and A. Rengakos, edd., Brill's Companion to Apollonius Rhodius, 2nd, rev. ed. Leiden/Boston: Brill, pp. 311-340.

Stahl, H.-P. (1985). Propertius. 'Love' and 'War'. Individual and State under Augustus. Berkeley: University of California Press.

Stephens, S. (2003). Seeing Double. Intercultural Poetics in Ptolemaic Alexandria. Berkeley: University of California Press.

Stephens, S. (2015). Callimachus. The Hymns. Oxford: Oxford University Press.

Thomas, R.F. (1993) Callimachus Back in Rome. In: M.A. Harder, R.F. Regtuit, and G.C. Wakker, edd., Callimachus. Groningen: Egbert Forsten, pp. 197-215.

Tueller, M. (2000). Well-Read Heroes. Quoting the Aetia in Aeneid 8. Harvard Studies in Classical Philology, 100, pp. 361-380.

Valladares, H. (2005). The Lover as a ModelViewer. Gendered Dynamics in Propertius 1.3. In: Ancona/Greene 2005, pp. 206-242.

Walde, C. (2008). Narration in a Standstill. Propertius 1.16-18. In: Liveley/ Salzman-Mitchell 2008, pp. 123-141.

Wallis, J. (2013). Reading False Closure in(to) Propertian Elegy. In: Grewing/ Acosta-Hughes/Kirichenko 2013, pp. 229-246.

Welch, T. (2005). The Elegiac Cityscape. Propertius and the Meaning of Roman Monuments. Columbus: Ohio State University Press.

West, M. (1974). Studies in Greek Elegy and Iambus. Berlin/New York: De Gruyter.

Wimmel, W. (1960). Kallimachos in Rom. Die Nachfolge seines apologetischen Dichtens in der Augusteerzeit. Wiesbaden: Franz Steiner.

Wohl, V. (2002). Love among the Ruins. The Erotics of Democracy in Classical Athens. Princeton: Princeton University Press.

Wyke, M. (1987a). The Elegiac Woman at Rome. Proceedings of the Cambridge Philological Society, 33, pp. 153-187.

Wyke, M. (1987b). Written Women. Propertius' scripta puella.Journal of Roman Studies, 77, pp. 47-61.

Wyke, M. (1989). Mistress and Metaphor in Augustan Elegy. Helios, 16(1), pp. 25-47.

Wyke, M. (1994a). Taking the Woman's Part. Engendering Roman Love Elegy. Ramus, 23(1-2), pp. 110-128.

Wyke, M. (1994b). Woman in the Mirror. The Rhetoric of Adornment in the Roman World. In: L. Archer, S. Fischler and M. Wyke, edd., Women in Ancient Societies. An Illusion of the Night. New York: Routledge, pp. 134-151.

Zanker, G. (1987) Realism in Alexandrian Poetry: A Literature and Its Audience. London: Croom Helm.

Zetzel, J. (1996). Poetic Baldness and Its Cure. Materiali e discussioni per l'analisi dei testiclassici, 36, pp. 73-100. 